\title{
Mercantilism and Bureaucratic Modernization in Early Eighteenth-Century France
}

Jean Beuve, Eric Brousseau, Jérôme Sgard

This version: April 13, 2015.

Abstract

French mercantilism is generally associated with absolutist policymaking subject to capture by rentseeking interests. This paper investigates how the Bureau du Commerce, a small agency in charge of commerce and the supply side, handed out rents and privileges to private entrepreneurs. We thus coded how it investigated and decided all 267 voluntary submissions received between 1724 and 1744. We show (i) that the Bureau's formal, rule-based decision-making process could actually differentiate between alternate policy aims and target them consistently over time, with more or less powerful sets of rents. From this (ii) we derive a hierarchy of revealed policy preferences. First comes technical innovation and diffusion, then local economic development; import substitution is only in the third position, followed by consumers' welfare. Lastly, and against a long line of authors, we show that the production of luxury-goods was not a significant or valued objective. 


\section{A new approach to Mercantilist policies}

The term 'mercantilism' is widely held to refer a broad period of European history during which absolute monarchs followed illiberal policies based on false premises: protectionism, widespread monopolies, and the confusion of wealth, money and power. However, beyond this broad and standard definition, it is difficult to identify a clear set of intermediary objectives and policy tools that would define more precisely what mercantilism was exactly about.

A well-known part of the problem, of course, is that the theoretical foundations of mercantilism are shallow. Contrary to what Adam Smith suggested, there is no single, logically consistent "mercantile system", so that on balance we may rather follow David Landes and conclude that there was just "pragmatism gilded by principle". Or should we rather join Joseph Schumpeter, for whom mercantilism was only "an imaginary entity"? But even if we discount these analytical limitations and look only at the historical experience, approximations and hearsay tend to dominate. For example, many authors take for granted that the overarching aims of mercantilist policies were to substitute domestic production for imports and to absorb foreign technology. But they rarely ask whether local development or technological diffusion at the domestic level were significant objectives as well, and, if yes, with what degree of priority. Another cliché is the supposed preference of many mercantilist policy-makers for the production of luxury goods. In his classic study, Heckscher (1935) argued that it was indeed a key priority, which made some sense in a country like France, where the demand of the aristocracy and the court was quite large. But he then added that, as a consequence, manufactures later missed the turn towards broader consumer markets and large-scale production, hence their long-term failure. This argument has resurfaced in a long series of contributions, many of which take as a standard the example of the Manufacture Royale des Gobelins, in Paris (e.g. Sombart, 1913; Boissonnade, 1932; Cole, 1939; Nef, 1940; Landes, 1969; Ekelund and Tollison, 1981). However, none of these authors ever tested the general validity of the initial proposition, nor the long-term effect suggested by Heckscher.

Beside this old discussion about mercantilist policy objectives and their hierarchy lies however an entirely different, second set of questions about the resources and capabilities of emerging state bureaucracies. Schmoller (1897) first defended the proposition that mercantilist policies, in fact, came together with the development of modern bureaucratic states, or the Rechtstaat. Beyond its origins in an age of absolutism, mercantilism is thus envisaged as a modern, forward-looking regime. The usual example cited for this is the French ministry of finance, known as the Contrôle Général des Finances, which was thoroughly reformed by Colbert (1661-1683) during the early reformist period of the reign of Louis XIV (1661-1715). Ekelund and Tollison (1981, 1989, 2006), later followed by Root (1994), reject however Schmoller's line of reasoning: in fact this state machinery would have only increased the overall capacity of the Crown to extract fiscal resources and redistribute them as rents, so as to maintain the socio-political equilibrium of this "natural state" (North et al., 2009). Both assessments are very general, however, in so far as they propose a very broad, undifferentiated view of this bureaucracy. They do not ask for instance whether parts of it could escape capture and corruption and work indeed as an agent of change, or whether 
different types of rents may have had different impacts. It is not actually a moot question whether progressive trends could work from within the Ancien Regime monarchy, even though the macro-picture is one of a low growth economy, slowly drowning into debt.

This article presents a novel approach to these two issues: mercantilist policy preferences and the underlying bureaucratic capabilities, with the latter being interpreted here as the capacity to align means and ends (or tools and preferences) in a time-consistent, rule-based, predictable manner. We take the case of the distribution of Privilèges de Manufacture; i.e. franchises and rents awarded to private entrepreneurs that operated outside the guilds. This policy had its origins under the guidance of Colbert and persisted until the Revolution though the personal will and discretion of the Contrôleur Général led progressively the way to a more rule-based process in the hands of the Bureau $d u$ Commerce: a small Paris-based department within the Contrôle Général that was in charge of trade and supply side policies. The period under review (1724-1744) was marked by well-established procedures (hence the availability of large archives) and also by supportive economic conditions thanks to, i.a., an extended cyclical upturn and the quasi-absence of wars. The fact that a total of 267 decisions were made during these two decades, out of a total of about 450 between 1700 and 1790 , suggests as well that this post-colbertist industrial policy experienced at that time a kind of golden age. Indeed, from the mid-century onwards, the influence of the mercantilist doxa would gradually decline under the onslaught of the more liberal physiocratic doctrine.

The point from which we start is that the packages of benefits handed out by the Bureau resulted from the manipulation of some twenty discrete regulatory variables, whose economic impact could not be expected to be additive. They include, for instance, tax breaks on inputs or on the entrepreneur's income, privileged access to some natural resources, or a territorial exclusivity. We use this multi-dimensional pattern as an instrument to test whether this bureaucracy was able, over two decades, to align franchises and rents on the characteristics of the projects: that is, whether it was able to first identify characteristics it wanted to support and then target them in a differentiated, time consistent manner. If our 267 decisions had followed an entirely erratic pattern, reflecting court politics or royal caprice, then we would probably not identify any structural policy bias.

Contrary to this reasonable expectation, we show that the Bureau du Commerce worked in fact as an embryonic policy instrument in the hands of the government: Decisions made on a case-by-case basis are proved to be consistent, so that over twenty years similar projects received indeed similar support. These more or less extended packages of benefits reveal therefore a stable hierarchy of policy preferences: these early policy-makers first supported technological innovation and diffusion, then local economic development, thirdly importsubstitution, then consumers' welfare; on the other hand, and contrary to the common wisdom, supporting luxury-good producers was definitely not a priority between 1724 and 1744.

Overall, we thus cautiously endorse the long intellectual tradition that associates mercantilism with state-building, or with an emerging practice of governmentality, rather than with capture, oppression and sterility. This conclusion applies however to the period under review only, and it does not imply any judgment, positive or negative, regarding the actual impact of this policy on the development of the French economy under the Ancien Régime. 
The rest of this article is developed as follows. We first briefly review the literature on mercantilism and show where exactly the present contribution fits in (Section 2). The next section discusses the institutional context of the time and how the Bureau du Commerce fitted in (Section 3). We then move to the investigation and decision-making process that underpinned the distribution of rents and franchises to firms and we describe the archives from which we built our dataset (Section 4). Econometric tests (Section 5) confirm that the Bureau had a proven and consistent capacity to target different policy aims, or preferences, with varied packages of privileges.

\section{Contrasting views of Mercantilism}

A first striking feature of the literature on the Mercantilist Age is that most historians of this era are typically cautious when appraising the effectiveness and impact of Colbertist industrial policies. Mantoux (1905), for instance, concludes that they had only "a limited scope" so that no link can be established with the subsequent industrial take-off. Goubert (1970), like Braudel (1979), states that most royal manufactures had "an artificial character", hence a limited capacity for survival without government support. With a slightly more optimistic view, Landes (1969) and Wallerstein (1980) conclude that these policies were "moderately successful" and that they might even had some long-term positive impact. What is thus remarkable in these conclusions is not just the care with which these authors avoid clear-cut judgments on the effects of these policies; they also resist any strong statement on the possible imprint of the mercantilist doctrine on the policies themselves.

In stark contrast, a second large strand in the literature fully acknowledges a normative, if not partisan, investment in the subject. A first line belongs to the old statist/nationalist trend in modern French political culture that originates during the last decades of the 19th century, in the monarchist, then nationalist glorification of the reign of Louis XIV (Lavisse, 1911). This view then took an economic turn during the interwar period (Boissonnade, 1932), so that in the post-war decades Colbert's policies were widely seen as the true origin of a dirigiste economic tradition. Today this romantic view still exercises a strong hold over a part of the bureaucratic and political elite. The most influential body of literature, however, has German origins, first in the writing of Friedrich List, and more clearly in Schmoller (1897), who, as said, was the first to closely associate mercantilism with the construction of a modern bureaucratic state: The link with the experience of the German Second Reich, in his case, is most explicit (Schmoller et al., 1899). But his best-known pupils and associates, Sombart (1913) and Weber (1927), were also close to this position. The theme later found a major extension in the landmark study by the Swedish economist Heckscher (1935) covering the whole European field, and which is nicely complemented by Cole (1939 and 1943), who focuses on the French experience.

This "German" tradition has been contested however by a third line of militant contributions which defend a positive rather than an intellectual perspective. As argued most forcefully by Ekelund and Tollison (1981, 1989, 2006), the proper approach to mercantilism should not start from ideas and social beliefs, but from the social and political conditions of the day, i.e. 
the rent-seeking character of the absolutist regimes; once on that positive basis, one may account for the actual policies as for the more or less sophisticated theoretical arguments that were supposed to back them up. Starting from such materialist premises, these authors reinterpret a fair part of the material collected i.a. by Heckscher and Cole and present a coherent though somewhat schematic view of the Ancien Régime bureaucracy as a kind of embryonic central-planning authority in charge of a detailed allocation of rents across the country. ${ }^{1}$ At this point, there is of course little point looking for economic policies in the modern sense of the word: registering and enforcing clientelistic deals across the country was all the royal bureaucracy was about.

Root (1994) offers a more nuanced and persuasive interpretation of the Ancien Régime, also based on an analysis of rent-seeking politics. Specifically, he pays much more attention to the rules of the game at the provincial level and the relationships between provincial élites, the monarchy, and the bureaucrats. This work is therefore more in line with the many monographs that have analyzed the role of social capital and political networks in the government of given cities or provinces (Bossenga 1991, Kettering 1986 and 1993, Mousnier 1982); it also echoes what is now known about Colbert's own clientelistic practices (Dessert 2001). However, Root's mostly local or provincial perspective does not have as much to say about the build-up of administrative capabilities, procedures, or new pools of expertise at the centre. He concludes nevertheless that "Paris and Versailles were transformed into elaborate centres of distributional play, since court politics determined what would be produced and who would benefit" (24); he later further defends the proposition that, in practice, "only a small coterie around each minister were thought to benefit [from rents]“ (p. 51).

Outside the public choice paradigm, Horn (2015) develops a novel and entirely opposite interpretation of privileges: rather than being a tool for systematic rent-seeking strategies, they would have worked primarily as an instrument to extricate the most entrepreneurial part of firms from the ramshackle institutional construction that was the Ancien Régime. Then, a number of other historians have studied mercantilist policy-making "in action", typically at the local level. Reynard (1999) for instance explored the evolving relationship between the state administration and the paperwork manufacturers of Auvergne, while Thomson (1982) and Johnson (1995) dealt in similar manner with the export-oriented textile industry in Languedoc. With an issue-based perspective rather than a local or territorial one, Szulman (2011) and Graber (2011) have recently explored the Bureau's policies regarding transport infrastructures, which they examine from a micro-level, project-based perspective. These works are complemented by Smith $(1995,2002)$ who focuses on how the Bureau du Commerce gradually constructed social and administrative networks within which actors could engage in a discussion framed, relatively early on, by liberal notions of public good and open-market competition. Smith (2011) on the Bureau, and Kessler's (2007) on the eighteenth century Paris traders court show in particular how these themes gradually side-

\footnotetext{
${ }^{1}$ According to Ekelund and Tolison (1981), the "French mercantile economy took on the form of a massive web of economic regulations administered by the central state" (84); hence, "the French nation-state as an extension and consolidation of monopoly power in the economy." (85), where the local bureaucracy, in the provinces, was primarily in charge of enforcing monopolies.
} 
lined the core mercantilist doxa and prepared the ground for the more liberal physiocratic discourse after 1750 .

Though often close to these later works, the present article does not focus on provincial politics, on the discourse and the values of social actors, or again on the evolving architecture of the absolutist monarchy. Instead, we look at how the Parisian Bureau du Commerce made decisions between 1724 and 1744 and whether its formal rules and procedures endowed it with some autonomy vis-à-vis its social and institutional environment, so that its decisions would remain consistent over time and across cases. Our point therefore is not to refute the widespread clientelistic character of the old monarchy. Archives are actually replete with personal demands for rents and favours, which are all very open and frank. The question we ask is to what extent formal bureaucratic rules and procedures were able to resist the pervasive pressure of rent-seeking politics and so provide ministers with a pliable policy instrument, strong enough to resist capture by the thousands of cronies and brokers that laid siege to their offices.

At this point, we should also remember that for Foucault (2004) mercantilism marked the emergence of a new model of governance: against the tradition represented by Machiavelli, with its insistence on sovereignty and on the preservation of the Prince's power, government would be about the needs and the welfare of the population, though also about the drive to control society, especially those who live on its fringes. In his view, this trend was associated with the gradual strengthening of l'Etat administratif (as opposed to the older, medieval Etat de Justice). The experience under review here may thus be seen a telling example where bureaucratization and mercantilist policy-making converge into in an early form of governmentality. $^{2}$

\section{Bureaucratic modernization and economic policy-making}

\section{Entrepreneurship under a weak, absolutist state}

Together with the patrimonialist character of the French monarchy, a further, serious obstacle to the emergence of a notion of public good, and of a public policy to serve it, was the minutely fragmented institutional and social structure of the Ancien Régime. In those days, there was no such thing as a representative royal subject, endowed with an identifiable package of rights in their modern, impersonal and abstract definition (Richet, 1973; Cosandey and Descimon, 2002). Individual statuses and franchises were defined by group affiliation, religion, guild membership and a wide array of coutumes, or customary laws, that were highly differentiated across and within provinces. On top of that, ad hoc privilèges was the typical way for superior authorities, starting with the king, to grant resources or franchises to individual or to entire social groups, like cities or guilds. Therefore, royal subjects were not only unequal; they were also thoroughly different, which is certainly not a good starting point for implementing government policies that would apply to all agents across the country (Brousseau et al., 2010). Still, the fact that this regime presented few formal checks and that

\footnotetext{
${ }^{2}$ See in particular, pp. 103-113 in Foucault (2004), lecture from February 1, 1978
} 
arbitrariness was a built-in option did not imply lawlessness: privileges, like those we are studying here, had a legal form and they were enforced by courts, hence they should not be assimilated to a casual bribe or a pension that the King would hand out and withdraw by fiat.

Indeed, the monarchy invested enormous efforts, over centuries, to integrate both the polity and the economy: this is what absolutism was ultimately about. It thus imposed the French language in all official occasions, unified the monetary order, constructed roads and canals, and attempted to reduce domestic customs and tolls. ${ }^{3}$ Critically, the Ancien Régime monarchy established a common legal framework for economic activities by enacting the 1673 Ordonnance sur le commerce - in practice, a rather light formalization of the old Merchant Law. These basic, impersonal rules were then enforced across the kingdom by elected merchants courts, or Cours Consulaires, which followed the traditional rapid-pace, free of charge practices of the merchants fair courts. ${ }^{4}$ Hence the policy of handing out differentiated packages of rents to private firms unfolded against the background of an economic playing field based at a relatively early jour on principles of universality and impersonality. We focus however on a single category of bureaucratic decisions: the awarding of privileges to private entrepreneurs. We do not deal, therefore, with the other pillars of this policy - the regulation of guilds by way of statutes, or the Règlements des Manufactures, who are dealt with by Thomson (1982) or Reynard (1999).

\section{The Bureau du commerce: an emerging modern bureaucracy}

From the 1660s onward, the driving force behind the attempt to integrate and develop the domestic economy was the Contrôle Général des Finances, akin to today's ministers of economy and finance. While remaining anchored in the Conseil du Roi, hence the King's personal authority, it developed a small corps of civil servants as well as its own territorial network of agents and offices. ${ }^{5}$ This is where a new model of administrative work was developed, based upon a streamlined division of labour, a top-down hierarchy, rules-based methods for investigating policy issues, well-kept files, etc. The size of this bureaucracy remained small, however, at least by today's standards: According to Felix (1997) the central offices of the Contrôle Général in Paris had a staff of about 100-110 persons by the 1770s and approximately 150 by 1789 - the local network in the provinces would have totalled some 540 persons by mid-century.

Whereas the Contrôle Général dealt primarily with fiscal and budgetary affairs, the Bureau $d u$ Commerce was created as a semi-autonomous department in 1700; a further advantage derived from the fact that it was not formally a part of the Conseil $d u$ roi, so that it could

\footnotetext{
${ }^{3}$ See Bosher (1970) and Conchon (2002) on tolls and internal tariffs; Daudin (2010) on market integration per se.

${ }^{4}$ On the Ordonnance and the Cours consulaires, see Lafon (1979), Hilaire (1986), Kessler (2007).

${ }^{5}$ On the literature on monarchic institutions and more specifically the Contrôle Général, see Bosher (1964), Mousnier (1985), Richet (1973), Bayard and Monnier (1997), Monnier (2003), Antoine (2003). On the bureaucrats per se, see Ricommard (1962), Gruder (1968), Antoine (1974), Felix (1997), Grevet (1998), Mukerji (2011). On the Commis as the real embryo of modern bureaucrats, Baxter (1980) and Felix (1997). See also Barbiche (2003), who asks rhetorically "what we don't know about the Contrôle" and then points out that its decision-making process has not been much explored.
} 
economize on the arcane rules that surrounded the exercise of the divine right to rule. ${ }^{6}$ It remained until 1791 in charge of the supply side of the economy (essentially the guilds and the manufactures) and commerce (domestic, colonial, and foreign). This is where postColbertist, mercantilist policies were actually debated and implemented. ${ }^{7}$ This large portfolio was managed by a body of some 20 to 25 persons, whose head was known until 1744 as the Directeur du Commerce. A Secretary took care i.a. of the correspondence of the Bureau and kept its official files, the largest part of which has been preserved until today. Then, four toplevel Intendants $d u$ Commerce were responsible for specific geographic areas and had authority over the lesser commis and the corps of Inspecteurs des Manufactures (Minard 1998). On the other hand, we did not include here the case of guilds' statutes or, for instance, the bargaining game between the Bureau and whole industries over the Règlements, as in Thomson (1982) or Reynard (1999).

Submissions for privileges made by entrepreneurs to the Bureau included a detailed presentation of the project, the technique it would use, the experience and competencies of the manager, the potential contribution to the local or national economy, plus a list of privileges that were deemed necessary for success. As we explore how these demands were then processed, a first feature that comes out is the systematic, wide-ranging attempt by the Bureau du Commerce to collect all significant information on the conditions that would weigh locally on the development of each project. Officials thus wanted to know about the availability or shortages of natural resources and workforce, or about the possible opposition from municipal authorities, local manufacturers who already had some privileges, or most typically from guilds. The archives of the Bureau therefore encompass a wealth of reports sent by government officials in the provinces, occasional letters by local authorities, expert opinions written by well-known merchants or members of the Academy of Science, etc.

Once all this information had been collected, decision-making proceeded through two colleges, where cases were discussed on an open, horizontal, peer-level basis. First was a group of 10 to 14 Députés du Commerce, who were well-established, experienced merchants, typically with a background in long distance trade, shipping, or banking. The Députés thus offered a deep expertise in matters of market practices, the law merchant, banking or the economic geography of both the Kingdom and foreign countries. The world of craft guilds and manufactures, on the other hand, was not strongly represented among the Députés, a feature that may have contributed to their readiness to seek external opinions in these matters.

\footnotetext{
${ }^{6}$ When created in 1700 the Bureau was to be attached to a Conseil de Commerce which, in turn, should had been part of the Conseil du Roi. This later body however never took hold so that the Bureau gradually emerged as a self-standing, permanent organization from 1708 onwards. After the period of relative disorganization that marked the Régence (1715-1724), it was the Bureau was given the status, organization and modus operandi that prevailed until the revolution. A Conseil Royal du Commerce was however established (again) in 1730, though without more success than its antecedent.

${ }^{7}$ The most comprehensive studies of the Bureau du Commerce are Schaeper (1983) who covers the first fifteen years of its existence (1700-1715), and Parker (1979, 1993), who worked on the years 1781-83. They both provide a fine description of its structure and mandate, as well as of its relationship with the ministers. Smith $(1995,2002)$ is another important reference (see also Bonnassieux (1900) and Wybo (1935)). On the Intendants du commerce - who constituted the administrative backbone of the Bureau and should not be confused with the Intendants, who were the representatives of the crown in the provinces - , read Schaeper (1983), Garrigues (1998) and Antoine (2003).
} 
Also, they most often had some experience with municipal government or the local traders' courts, after which they had been elected to the Bureau by the largest trading cities, most commonly via the local Chambers of Commerce. ${ }^{8}$ The fact that these cities paid for the living expenses of the Députés clearly supported the expectations that the later would act indeed as lobbies. The bilateral correspondences between the Députés and the local officials reflect however a lot of tensions and frustration city officials: $:^{9}$ contrary to what their name suggest, the Députés did not speak in Paris with the authority and the legitimacy of democratic representation. Discursively, they rather argued in the name of "the good of commerce", which was framed as a fully legitimate sub-part of the public good, or of "the good of the kingdom" (Kessler 2007). A good way to describe them may thus be as a body of consultants, on de facto long-term contracts awarded with the expectation of an asymmetric allegiance first to the royal bureaucracy, then to their city. The second college was made of the core officials from the Bureau du Commerce and representatives of various branches of the royal administration.

On a case-by-case basis, decision-making started with a thorough discussion within the college of Députés based on the submission provided by the applicant, plus the reports and opinions collected by the Bureau. A detailed and motivated collective Avis conveyed their opinion and recommendation to endorse, reject, or amend the demand. The Avis and the all file were then sent to the second deliberative college who discussed again the whole submission and wrote a draft decision to be submitted to the Minister. The Députés attended these plenary meetings though, at this point they had no say in the deliberation.

Even though he was not formally bound by this recommendation, in almost all cases Contrôleur Général des Finances endorsed it without modification. ${ }^{10}$ The fact that this advice came with a comprehensive, carefully worded justification underlines further the modern, impersonal character of the overall process. The Minister acted as if he trusted this rulebased, information-driven, pluralist decision-making process offered him the best advice he could obtain. At least from a formal perspective, this bureaucratic process is quite different from the cliché of a highly-centralized body, working in a few closed rooms at Versailles, a corridor away from the king and his courtiers.

In both colleges, the deliberation revolved most explicitly around the question of how to balance market competition and the protection of innovators and risk-takers. This was stated rather solemnly by the Députés in 1724, when they wrote that the Bureau « has always been defending the principle that exclusive privileges would be granted only for new inventions. Those who asked for them in order to produce things already known and produced in France have always been rejected. This rule is entirely grounded on Justice and the protection that the King owes to all his subjects, as on the equality and competition which Commerce

\footnotetext{
${ }^{8}$ In principle, the Députés had to be elected on a yearly basis, but very soon after the establishment of the Bureau in 1700, new rounds of elections were abandoned and members were either renewed on a routine basis, or appointed by Parisian bureaucrats to replace the outgoing Députés.

${ }^{9}$ Read for instance Quenet (1978) on the Députés from Nantes; Labraque-Bordenave (1889) on the case of Bordeaux, Pariset (1887) for Lyon, and Fournier (1920) for Marseille.

${ }^{10}$ In the cases we investigated, we found just one example of the Ministry not endorsing the recommendation of the Bureau.
} 
demands. Indeed, the favours that would be given to some would only give them superiority over the others, and would thus tend towards the destruction of Commerce and manufactures." (Avis des Députés, December 22, 1724).

Beside innovation, the development of backward regions, for instance, could justify as well public intervention, as argued for instance in the 1729 case of a large, low-quality textile manufacture to be established in Valence, south of Lyon: " the purpose of this project is to set up a new factory in a country where trade should be restored; there must be a happy example to awaken the courage of Peoples; the Entrepreneur will have to make big expenses in a firm from which the King and the Province can expect great benefits, since this will prevent skilled workers [from leaving the country], will provide for the consumption of products originating in the Province (...) and finally the city of Valencia will repopulate ... " (Avis, Intendant du Dauphiné, May 17, 1729).

\section{The logic of granting Privileges}

\section{Collected data}

In order to analyse systematically how privileges to private entrepreneurs were granted in practice, we built a database that includes all 267 submissions made to the Bureau between 1724 and 1744 . We thus systematically collected and coded the main characteristics of each submission as of the whole deliberation and decision-making process. ${ }^{11}$ We rely primarily on the Avis des Députés, the contributions of the provincial Intendants, and the minutes of the deliberations of the Bureau. In most cases, these sources allow us to identify the content of the initial application; the position and arguments brought forward by the other voices involved in the investigation; the conclusions reached at the plenary meeting of the Bureau; the final decision with the list of privileges that were actually granted, and the official justification that backed them up. In addition, we also collected additional variables that we used for various controls: each project is identified in terms of localization and jurisdiction, date, and industry. Lastly, we identify with a dummy variable the ventures that targeted luxury goods and those where a foreign entrepreneur or a nobleman was a party. ${ }^{12}$

Table 1 summarizes the main features of the applications in our sample. Close to $10 \%$ of them are requests based on innovation. The remaining cases are industrial ventures in a broad sense - they cover natural resource exploitation projects, such as mines or new crops; all kinds of factories, mainly in textile, metal and earthenware; and some services (e.g.

\footnotetext{
${ }^{11}$ Our database has been built entirely on the archives of the Bureau du Commerce which kept at the Archives Nationales (Fond $\mathrm{F}^{12}$ ); see Bonnassieux (1900) for a most useful inventory. We relied on three types of documents: i) the minutes of the Bureau ( $\mathrm{F}^{12} 51$ to 91), with at least three entries for each case (deliberation and recommendation, decision by the Minister, draft of the official decree); ii) The files and the personal notes left over by the Secrétaire of the Bureau or its members ( $\mathrm{F}^{12} 662-670$ and 685 to 704$)$; iii) The Avis des Députés $\left(\mathrm{F}^{12} 693\right.$ to 724$)$ that provide a precise description of each project, and add a cross-regional or sectoral perspective, and references to similar cases submitted earlier to the Bureau. .

${ }^{12}$ To our knowledge, this article is the first ever systematic analysis of the distribution of Privileges for manufactures by the Bureau. Deyon and Guignet (1980) explicitly denied that any quantitative approach might be viable on this subject. The closest approach to the one adopted here, though applied to a very different institutional and political context (namely 18th century England), is Bogart $(2005,2011)$.
} 
transportation, warehousing), among which almost two-thirds are new ventures; the remaining third are submissions for a renewal or an extension of an already granted privilege.

- Table 1 around here -

\section{Rubber-stamping: Can we trust the data?}

Before we move forwards and analyse how this industrial policy was conducted, we have to consider however the possibility that the description on individual projects might have been endogenous to the final decision of the Bureau. Indeed, we cannot directly observe the intrinsic characteristics of projects, neither can we rely on the descriptions provided by the entrepreneurs themselves: they typically envisaged a grand and glorious future for their firm while also harbouring preconceptions about what the Bureau wanted to read and support. Last but not least, the Bureau itself could have been only a façade behind which rents would have been handed out "as usual", following external factors like court politics or local clientelistic deals. For the following three reasons, we think however that our database is not strongly biased, hence that there is no endogeneity flowing backwards from the final decisions to the project descriptions.

First, as said, the whole process at the Bureau was structured to gather as much information as possible on each project, a priority that inevitably came at a cost. The decision procedure was thus 'open' in the sense that, in both colleges, ${ }^{13}$ the parties were provided with all the available information and all competing opinions: they thus had to argue publicly given the arguments brought forward by all other participants in the process. Rule-based, collegial deliberations thus worked de facto as an instrument of mutual control. At the same time the diversity of professional and social backgrounds (noble vs. commoner, Parisians vs. provincials) did not leave much room for a powerful esprit de corps that would have come in turn with the collective, implicit adhesion to a given coherent set of legitimate policy aims. In another investigation of these data (Beuve et al., 2014) we have actually shown that the final decision was indeed aligned on (or predicted by) the opinions voiced by the key participants during the deliberations inside the Bureau, and on the actual, substantive arguments they raised (e.g. the actual degree of innovation represented by the project).

Second, this rather complex procedure operated in an environment in which rent-seeking politics were played out in full daylight. Discounting the intrinsic value of the formal rules of the Bureau, on a prima facie basis, would thus beg the question of why this sprawling patrimonialist power system would have invented a machinery so entirely at odds with its own modus operendi (Antoine 2003, Parker 1979, Shaeper 1983). In a regime devoid of Parliamentary or media oversight there was no compelling reason to show off accountability.

\footnotetext{
${ }^{13}$ This was also true for the local representatives of the Ministry of Finance in the provinces (the Intendants): when their reports were deemed incomplete or biased by the colleges they were asked to deepen their investigations and to provide more informed opinions.
} 
Lastly, we systematically checked in the archives of the Contrôle Général for possible signs of outside influence or for signs that some entrepreneurs could actually bypass the Bureau. First, there is no trace in the archives of the Bureau of any demands or pressure by the outside stakeholders, or patrons, on its officials. Neither did we find any written instructions from the Ministry of Finance, or any other Ministry, pertaining to individual claims under investigation. Second, and more importantly, since most applications were addressed to the Contrôleur Général, i.e. the principal of the Bureau, we have systematically checked its remaining correspondence, either with other officials or with private persons. ${ }^{14}$ While we found hundreds of demands, acceptances and rejections of personal rents and appointments each year, only four letters concerned manufactures: In each of those cases, the Minister refused to intervene in the process.

In 1739 for instance the Contrôleur Général received a letter from the blue-blood Princesse d'Armagnac, certainly a person with easy access to the Court, who soon received a most elegant answer: "I received the letter you did me the honor to write in favour of the glassware entrepreneurs in Sevres. These men have long been serving badly the interests of the King, those of the public as well as their own ones. It is therefore very desirable that the Company can pass into the hands of people who would make more out of it. In addition, this case being now in the hands of the commissaries of the Conseil [du Commerce], I can not decide anything by myself and would not do anything that would oppose the free course of justice. I beg you to be convinced of the respect with which I have the honor to be, Madam, your very humble servitor. " (August 9, 1739).

We do not argue of course that the Bureau was entirely immune from pressure and that attempts at manipulating it were always foiled. There are many examples of bribes being handed out, from the very bottom to the very top of the Contrôle (Schaeper 1982). We only defend that decision-making regarding privileges to firms was not systematically captured, so that the de jure rules of decision-making were reasonably aligned with the de facto rules, i.e. that privileges were granted on the basis of the collectively acknowledged characteristics of each real-world project. Moreover, if this rule had been systematically violated, that is if privileges had been handed out on other grounds, say princely caprice or court politics, then there is good reason to believe that econometric test would not reveal any stable, significant set of policy preferences.

\section{Privilèges: a Menu of Franchise and Rents}

The 'menu' of privileges from which individual applicants could draw can be grouped into four main blocks: a legal right to operate a business, a territorial exclusivity, personal tax reductions, and custom duties exemptions. On top of this, a further set of miscellaneous

\footnotetext{
${ }^{14}$ To check for pressures that might have been exercised during the process, we reviewed the remaining correspondence from the Ministry of Finance over the period $\left(\mathrm{G}^{7} 31-61\right)$. We also checked its incoming correspondence: i) from the provincial Intendants (index G7 71 to 531); ii) and from private persons (G7 601602). We also checked the official requests sent to the Ministry by individuals (i.e. the 'Placets'; G7 675-680).
} 
franchises were rarely requested or granted, and so they are ignored in the rest of this paper. ${ }^{15}$ This classification presents the advantage of allowing for a form of ordering within each of these four blocks, thanks to the relative homogeneity of the respective privileges. We shall thus use this ordering as a "quasi-metric", or a proxy for a measure of the "intensity" of the privileges being requested and/or obtained by each project. This "intensity" reflects the number of privileges granted when they are cumulative (e.g. tax cuts) or the scope of the privilege when they can be ranked.

Block One. Submissions made by entrepreneurs first included the application for a legal status, allowing him to establish the firm; i.e. to begin producing and selling goods. Then, the investor could ask for a "Privilège exclusif" which provided more institutional leverage but generally implied compliance with statutory regulations (especially in the textile industry); his firm would often be called a "Manufacture". Last was the status of "Manufacture Royale" that added a degree of grandeur in a society where symbolic display was a tangible resource. ${ }^{16}$ Hence in this first block the "intensity" measures takes (quite intuitively) the form of an ordinal variable equal to 0 when no specific right of production is granted, 1 when the Bureau authorizes to produce the good or the service (RightToProduce), 2 when the Bureau award the status of manufacture (Manufacture), and 3 in the case of a "Royal manufacture" (RoyalManufacture).

Block Two addresses territorial exclusivity. Here is the monopolistic feature that has attracted a lot of attention, primarily by Ekelund and Tollison $(1981,1989)$ and Root (1994). However, these exclusivities came with two important caveats. First, their spatial extent was generally limited to a perimeter of less than 20 or 40 kilometres (i.e. 5 to 10 lieues, according to the old units) around the firm; sometimes it covered a given province, and most rarely a monopoly franchise over the whole kingdom. In this latter case, the privilege concerned a technological innovation (possibly imported) and so resembled a modern-day patent. The second caveat is that (except for these quasi-patents) exclusivity did not imply market closure, but covered the ability to produce only: outside competitors could enter the local market, so that the competitive advantage for the protected producer was a function of transportation costs and internal tariffs. Beside, the way exclusivity provisions were discussed by the Bureau reflects the clear assumption that they were exceptions to the rule of market competition: their aim was either to guarantee to the entrepreneur a given income stream, or to limit the pressure on scarce local resources, such as wood or fresh water. Note also that the monopolies that were granted by the Bureau had no fiscal counterpart: The privileges did not serve as an instrument for the administration to extract revenue indirectly from the economy, as in the case of tax farms, salt mines or the tobacco monopolies. The derived intensity variable Exclusivity again

\footnotetext{
${ }^{15}$ Among these miscellaneous benefits are for instance the possibility for noblemen to take part in the project without forfeiting their nobility; subsidies or loans (very rarely) granted by the Crown; direct access to the consumer market, thus de facto bypassing the merchant guilds; or, when there was a perceived risk that opposition to the project could coalesce around the local or provincial jurisdictions, the Bureau could decide that any future dispute would be settled by the central administration.

${ }^{16}$ See Bondois (1933) for a presentation of these types of firms; he differentiates neatly between the Manufactures Royales, which were private businesses, and a limited number of Manufactures d'Etat: these State-Owned Entreprises belonged in fact to the royal domain and were not operating under market constraints. Les Gobelins are the best-known example. See also Horn (2015).
} 
takes the form of an ordinal variable, set to 0 when no territorial exclusivity is granted, 1 when the producer' monopoly is strictly local, 2 when it extends to the whole province and 3 when it covers the whole country.

Block Three consists of personal tax exemptions targeted at the entrepreneurs and their business partners, occasionally skilled workers - or ouvriers. These exemptions could apply to taxes in kind, like serving in the local militia or hosting soldiers from the royal army (intensity variable Taxes take value 1); or, more rarely, breaks could also extend to monetary taxes on income flows, like the taille (resp. 2).

Block Four includes tax exemptions that directly affected the competitive position of the firm; hence they presented a potentially much more distortionary character than the previous ones. We here find custom duties on imports and exports and, more importantly, internal tariffs and tolls that proliferated between provinces, at the entry of cities, or along roads and rivers. We differentiate here between taxes on inputs (the ordinal variable CustomTax takes value 1) and on outputs (resp. value 2).

\section{No Easy Access to Privilèges}

The first evidence that emerges from our dataset is that success was in no way guaranteed: a significant proportion of submissions were rejected (28.5\%) and an equivalent share $(29.2 \%)$ received less than initially requested. The balance $(42.3 \%)$ corresponds to fully successful submissions. Figure 1 also shows that entrepreneurs who submitted demands to the Bureau had little chance of obtaining benefits in all four blocks of possible privileges. There was a clear pattern of only granting two "components": a status and either a territorial exclusivity or a tax cut on income and/or custom duties. Only $4.8 \%$ of the claimants were able to obtain privileges pertaining to all four categories. This observation is also reflected in the table of correlation (see Table A1 in Appendix) showing that there is only a weak correlation among the four categories of advantages granted: ranging from 0.200 to 0.498 . This should be taken as a first indication that the different sets of privileges were indeed granted on the basis of alternative justifications given the heterogeneity of the projects.

— Figure 1 around here -

For instance, Figure 2 highlights that the title of Manufacture was granted in only half the cases, and most projects that applied for a territorial exclusivity were simply not granted any such benefit. When they did receive one, it was mostly local in nature, and national exclusivity was clearly exceptional $(7.9 \%$ of cases) as we have already mentioned. The personal tax exemptions that were most frequently awarded were the less costly ones (civic duties), and even these were granted to only one-fifth of the projects. Finally, these tax cuts were more common than exemption from (internal) customs duties (more than $80 \%$ of demands were rejected). 


\section{Policy objectives}

As we coded all the substantive motivations brought forward during deliberations, we identified up to 30 different arguments (see Table 9 in Appendix). Some of them are raised frequently, and others hardly ever. We take the ten arguments most commonly acknowledged by the Bureau as reflecting, in practice, its main policy objectives that actually drove decisions (see Table 3 and Table A2 in the Appendix).

These arguments, ranked by their frequency of occurrence, are dummy variables set equal to 1 when the Bureau recognizes the quality of products (Quality), the potential to reduce imports or contribute to exports (TradeBalance), the contribution of the projects to the development of the local economy (LocalEconomy), the benefits that can be expected for consumers in an economy characterized by supply shortages (Consumer), the requested capital to start the project (FixedCosts), the contribution to technological development through invention or the importing of a foreign technology not domestically available (Technic.Innovation), the ability of the projects to develop local resources such as commodities and minerals (Val.LocalResources), the positive impact on employment of the poor (SocialEmployment), precedents (PriorPrivileges), and the need to attract specialized labor, often from abroad (Attract.LaborForce).

Note however that these "policy objectives" were not stated by the administration ex ante: there was no "Call for Projects" that would have invited entrepreneurs to submit projects targeting this or that policy objective. Entrepreneurs selected from an informal list of potential outcomes that had been de facto recognized as legitimate motives for public support. The fact that intermediaries might have helped them preparing their submission, as suggested by Schaeper (1983), is not problematic for our perspective, as long as it is not established that these were in fact patrons.

We can thus see in Table 3 that this list of revealed policy aims is larger and far more diverse than what the common discourse on mercantilism usually recognizes. Quality of products and import-substitution are in fact the most frequent, though development of the local economy is the third most common policy goal at this point. Yet an interest in the local employment (typically the poorer part of the population) or a better exploitation of scarce natural resources is also regularly mentioned as a valid argument, both in the submissions and the appraisals of the Bureau. A simple cross-section analysis of how privileges were distributed among classes of projects allows for a first, simple measure of where the Bureau puts more resources: i.e. which characteristics (like Quality or TradeBalance) were more supported, as a whole, than others.

\section{Empirical Analysis}




\section{Identification strategy}

We now estimate different versions of the following equation:

$$
\text { PRIVILEGES } S_{i}=\alpha_{i} \text { ARGUMENTS }+\beta_{i} \cdot Z_{i}+\varepsilon_{i}
$$

where PRIVILEGES $S_{i}$ is the dependent variable for each individual application $i$, ARGUMENTS is our vector of independent variables that includes the ten most frequent positive motivations put forward by the Bureau to justify granting advantages; and $Z_{i}$ is a vector of control variables. $Z_{i}$ contains dummy variables reflecting whether the firm is to produce luxury goods (Luxury) and whether the firm is to be managed by foreign entrepreneurs (Foreigner), as well as the date of the decision (Year), in order to check whether our results might be driven by a time trend. Controls also take sector-group dummies into account to control for possible effects due to sector preferences. Ideally, we would also like to consider fixed effects due to regional dimension but the requests for privileges are from 38 different provinces, thus we cannot introduce region-dummies without prohibitively reducing the degrees of freedom of the (ordered) logistic models. To limit the potential impact of the problem and to account for potential heteroschedasticity and auto-correlation of the error terms within geographical areas, we cluster standard errors at the regional level in all of our regressions. While keeping our set of explanatory variables unchanged, we run estimates using different dependent variables so as to extract maximum information on the way policy-makers adjusted means (privileges) and ends (their preferences).

In a first step, we investigate the likelihood that the applicant will obtain a privilege pertaining to one the four Blocks, depending upon the character of his business project. Hence, we construct a first dependent ordered variable, Obtained, which takes values 0 to 4 and stands for the number of different Blocks of privileges among which the claimant obtained at least one individual benefit. This corresponds to model 1 in Table 4. Then, we look separately at each of the Blocks and assess the determinant of the "intensity" of the granted privileges, as described above. This leads to models 2, 3, 4, and 5 in table 4. Finally, to observe if some features of the projects have a specific impact, we run logit estimates for each dummy variable corresponding to each individual advantage that could be granted by the Bureau du Commerce. This results in models 11 to 13 for the status of producer (Table 6); 14 to 16 for the territorial exclusivity (Table 7); 17 and 18 for per-capita tax cuts; 19 and 20 for custom duties exemptions (Table 8).

\section{Empirical results}

\section{Revealed policy preferences}

The results of model 1 in Table 4 go a long way to revealing the hierarchy of policy objectives of this post-Colbertist, mercantilist policy. Project features that received the broadest support were, in declining order, those contributing to: (i) technical innovation and diffusion; (ii) local economic development; (iii) a stronger trade balance; (iv) increased supply and consumers' welfare. This is confirmed by the results of model 6 in Table 5 which provides marginal effects. Indeed, it indicates that the probability of not obtaining any 
privileges $(\operatorname{Pr}($ Obtaining $)=0)$ is $30.4 \%$ lower when a project is considered as innovative (TechnicInnovation $=1)$; when all other independent variables are set at their mean value. This probability is respectively $24.4 \%, 20.3 \%$, and $16.1 \%$ lower for projects that favour local development (Local.Development), import substitution (TradeBalance) and the consumers' welfare (Consumer). Further to these four main policy objectives we observe, though with a less significant coefficient and lower marginal effects, a positive impact of product quality, and possibly the presence of high fixed costs or the exploitation of local resources.

— Tables 4 and 5 around here -

Our results then infirm two common statements of the literature on mercantilist policies. First there is not indication that attracting foreign entrepreneurs or technicians within the kingdom was a priority during the period under review (see Foreign, and Attract.Labor.Force). Second, and more important, the control variable Luxury remains remarkably silent in those first regressions, as well as in all subsequent ones. Hence, this post-Colbertist industrial policy of the early eighteenth century was not driven by a preference for luxury good producers, contrary to what Heckscher and a long line of authors have argued. If anything, this factor has a negative impact on the probability of receiving privileges. In fact, this policy line is not only revealed by econometric testing, it surfaces quite often in the minutes of the Bureau, like in the following 1731 case, where a submission by a silk producer from Lyon was rejected on the ground that "it would be better for the manufactures of Lyons that workers who have superior qualifications exercise their talents in ways that would help them meeting more readily the tastes that dominate in this country, where we prefer fabrics from Holland or India to ours, because they are softer, more handy, lighter and less expensive than those that are done in Lyon" (Bureau, 15 february 1731).

\section{Blocks of privileges and their "Intensity"}

On top of these were first evidences of a bureaucratic capacity to aligns policy tools and ends in a consistent manner, models 2 to 5 in Table 4 show in greater detail how the four main Blocks of privileges were targeted at differentiated types of projects; this information is then confirmed and extended by Tables 6, 7 and 8, which evaluate how the determinants of the "intensity" of support, within each block of privileges, were affected by the underlying preferences of policy-makers. We may thus move from a more quantity-based approach of the volume of privileges granted and a more nuanced understanding of how they were differentially mobilized by the Bureau.

— Tables 6, 7 and 8 around here - 
Technical innovation is typically supported by two instruments: the right to produce (though rarely with the status of Manufacture Royale), and national exclusivity. ${ }^{17}$ As highlighted in model 8 (Table 5), the probability of receiving a privilege of territorial exclusivity was $68.7 \%$ lower when the Bureau did not recognize the presence of technical innovation. Note, however, that these two benefits were awarded jointly, so that this class of project was not associated with an intellectual property right in the modern, impersonal sense. National exclusivity required the establishment of a factory.

Local development should be understood as the overall development of productive capabilities in a given district, with its multiple impacts (e.g. on the demand for labour), or in terms of providing intermediary goods or fostering demand for existing business. This important (and often neglected) dimension of mercantilist policies is typically supported by, i.a., the status of manufacture (2) and some territorial exclusivity (6), though only at the local level (models 14 to 16 , Table 7). ${ }^{18}$

Supporting the Trade Balance - typically considered the key mercantilist target - often motivated awarding the status of Manufacture, a regional (or provincial) production monopoly and substantial support in the form of custom duty relief, which directly affected the production function (resp. the investors' personal revenue). Here again, the marginal effects indicate that the probability of not benefitting from custom duties exemptions is $14.6 \%$ lower when there is an expectation that the project will reduce imports. Although this is not the highest rewarded policy objective of the Bureau du Commerce, it received the types of support that were already perceived, in those times, as most distortionary.

Quality of production is clearly valued by the Bureau $d u$ Commerce, though this characteristic does not attract a typical set of privileges: Discussions at the Bureau indicate that it was only a factor when awarding the status of a Manufacture Royale.

This series of elements thus confirms both the presence of a clear hierarchy of policy preferences in the decisions made by the Bureau, and a bureaucratic capacity to align tools on preferences in a consistent manner over a twenty years period. Furthermore, we also see that some policy instruments were designed to attain a more diffuse set of goals whose impact does not show up econometrically. The concern for the development of local resources, for example, comes up regularly in the minutes of the Bureau and in the Avis des Députés, though support for this policy objective was rather diffuse in terms of the instruments used, and is thus not captured by our tests.

\footnotetext{
${ }^{17}$ Technological innovation came in two contrasted forms: either as a stand-alone submission, or in the context of an industrial venture. In the former case, the applicant claimed for an exclusive and tradable right to exploit. Since the institutional infrastructures did not allow implementing them, the applicant could receive a grant, and his innovation would fall in the public domain (10\% of the innovations in our sample; see Scotchmer (2004) on this practice in pre-modern Europe). In the case of an industrial venture, the claimant usually received a right to produce, though not a statute of manufacture, combined with a national territorial exclusivity. Often, a privilege of direct distribution was added as way to protect his innovator's rent from intermediaries.

${ }^{18}$ Interestingly, the decision makers established a difference between the businesses that were supposed to have effects on development in general, and those who were simply addressing local contingencies, like shortages, or scarcity of natural resource, such as mines, crops, and fresh water.
} 


\section{Fine Tuning}

We focus here on arguments that rank second in the matter of "ends", as compared to the one highlighted in the two previous sections. What the analysis highlights is the fine-tuning of the alignment of the granted privilege with the objectives. Second tier goals bring less crucial benefits, and again one can see how well they are aligned. As an example, the recognized quality of the output is the essential argument to obtain the status of Royal Manufacture (see model 13 in Table 6), but it does not bring additional benefits. Note also that the contribution to trade is not crucial for this distinctive status, confirming both the error of the dominant vision of the goal of these establishments, and the apparent high marketing value of the government's endorsement of the quality of a production.

Other illustrations of the capacity to fine-tune policy targeting are also seen, for instance, in the determinants of per-capita tax cuts. They are driven by the necessity to attract skilled labour and by the existence of precedents. In the latter case, precedents play essentially on non-monetary taxes (CivicDuties; see model 17 in Table 8). This is a further econometric illustration of the willingness of the Bureau to limit distortion of competition by preferably granting privileges with a low impact on competition, and to grant them on a fair basis - i.e. similar bonuses to substantially similar projects.

\section{Endogeneity Issues}

Our empirical strategy defines the outcome of the decision process as a dependent variable and characteristics of the projects for which the entrepreneurs seek privileges plus characteristics of the entrepreneur and his business as the explanatory variables. The positive aspect is that we do not have endogeneity issues related to a possible reverse causality. Indeed, the outcome of the decision comes down in the decision-making process, once the various arguments have been put forward by the parties on the basis of prospective assessments concerning the nature of the project. However, the problem may come from the fact that all explanatory variables are likely endogenous. Therefore, the variables on the righthand-side of the equation would be both explanatory and explained, which may lead to misleading results. For instance, a technical innovation can be the source of more productivity and differentiation, enabling lower costs optionally associated with higher quality. Therefore, our variable Technic.Innovation would be positively and significantly correlated with our variables Consumer, Quality and TradeBalance. However, the statistical observation shows that the arguments used to justify the final decision are only weakly correlated (see Table A1). The average correlation between the arguments is 0.096 and the highest correlation between two arguments is 0.381 (between Quality and TradeBalance). Moreover, the most frequent number of arguments used is 2 (23.6 \% of cases) and no cases concentrated all the 10 arguments (the highest number of arguments put forward in a single case is 6 and affects less than approximately $2 \%$ of the sample, i.e. 5 cases). This suggests that the arguments are mobilized only when they are considered real characteristics of the project and that, de facto, endogeneity issues are not particularly acute at this point. 


\section{Conclusion}

We have reconstituted and coded the bureaucratic process by which the Bureau du Commerce made the 267 decisions on the requests for privilèges de manufacture submitted by private entrepreneurs between 1724 and 1744 . On that basis, we shown that this rulebased, information-driven, open process of deliberation could indeed differentiate between policy aims and consistently target them with different packages of franchise and rents. A hierarchy of revealed policy preferences was thus identified: these mercantilist policy makers targeted in the following order technical change, local development, the trade balance, and consumer welfare. We take these results as an indication that decision-making was relatively free from capture and that it also avoided the symmetric risk of bureaucratic confusion and erratic decision-making.

The way the Bureau du Commerce supported individual manufacturers thus reflects the attempt, by a emerging rule-based, impersonal bureaucracy, to weigh as "from the outside" on the economy's spontaneous development in directions deemed conducive to the common good - whether defined as industrial catch-up, import substitution or otherwise. In other words, the King's men would not just deploy forces and resources unilaterally and occasionally target opposition. Here, they rely upon signals and incentives at individual economic agents, who are expected to respond in ways that indirectly contribute to the ultimate objectives of the policy makers. And in this attempt the Bureau relies on instruments that are typical of modern governments: information, technical competencies and procedural consistency, and collegial decision-making. 


\section{References}

Abakane, H. 1967. La crise de 1724-25 et la politique de déflation du contrôleur général Dodin. Revue d'histoire moderne et contemporaine. pp. 266-83.

Antoine, Michel. 1974. La notion de subdélégation dans la monarchie d'Ancien Régime. Bibliothèque de l'école des chartes. 132 (2), pp. 267-87.

Antoine, Michel. 1989. Louis XV. Paris : Hachette. 1052 pages.

Antoine, Michel. 2003. Le cœur de l'Etat. Surintendance, contrôle général et intendances des finances, 1552-1791. Paris: Fayard, 592 pages.

Brousseau, Eric, Yves Schemeil and Jerome Sgard. 2010. Bargaining on Law and Bureaucracies, A Constitutional Theory of Development. Journal of Comparative Economics, 38 (3), 253-266.

Bayard, Françoise et François Monnier, dir. 1997. L'Administration des Finances sous l'Ancien régime. Colloque, Bercy, février 1996. Paris.

Biollay, Léon. 1885. Etudes Economiques sur le xviii ${ }^{\circ}$ siècle. Paris : Guillaumin. 547 pages.

Bogart, Dan. 2005. Did Turnpike Trusts Increase Transportation Investment in Eighteenth-Century England? Journal of Economic History. 65, pp. 439-468.

Bogart, Dan. 2011. Did the Glorious Revolution Contribute to the Transport Revolution? Evidence from Investment in Roads and Rivers. Economic History Review. 64, pp. 1073-1112.

Bonassieux, Pierre, Lelong, Eugène, 1900. Conseil de Commerce et Bureau du Commerce, 17001791, Inventaire analytique des procès-verbaux. Paris, Imprimerie Nationale, lxxii-699 pages.

Bondois, Paul-Marie. 1933. L'organisation industrielle et commercial de la France sous l'Ancien Régime: le privilège exclusif au xviii ${ }^{\circ}$ siècle. Revue d'Histoire Economique et Sociale. 21, pp. 140-198.

Boscher, J. F. 1964. The Premiers Commis des Finances in the Reign of Louis XVI. French Historical Studies, 3 (4), pp. 475-494.

Bosher, John F. 1970. The Single Duty Project: A Study of the Movement for a French Customs Union in the Eighteenth Century. London, Athone.

Bossenga, Gail. 1991. The politics of privilege. Old regime and revolution in Lille. Cambridge: Cambridge University Press. 262 pages.

Cole, Charles Woolsey. 1939. Colbert and a Century of French Mercantilism. New York: Columbia University Press. 2 tomes, 531 p. et 674p.

Cole, Charles Woolsey. 1943. French Mercantilism, 1683-1700. New York: Columbia University Press. 354 pages.

Coleman, D.C., ed. 1969. Revisions in Mercantilism. London : Methuen \& Co. 213 pages.

Conchon, Anne. 2002. Le péage en France au xviii siècle. Les privilèges à l'épreuve de la réforme. Paris, Comité pour l'Histoire Economique et Financière de la France. 583 p.

Cosandey, Fanny et Robert Descimon. 2002. L'absolutisme en France, Histoire et Historiographie. Paris: Le Seuil. 316 pages.

Daudin, Guillaume. 2010. Domestic Trade and Market Size in Late 18th century France. Journal of Economic History, vol. 70 (3), p. 716-743.

Dessert, Daniel. 2001. Colbert ou le serpent venimeux. Bruxelles: Complexe. 168 p.

Dessert, Daniel. 2007. Le royaume de monsieur Colbert. Paris: Perrin. 304 p.

Deyon, Pierre and Philippe Guignet. 1980. The Royal Manufactures and Economic and Technological Progress in France before the Industrial Revolution. The Journal of European Economic History. 9 (3), pp. 611-632.

Ekelund Robert B, and Robert D. Tollison. 2006. On neoinstitutionalist theory and precalssical economies : mercantilism revisited. The European Journal of the History of Economic Thought. 4 (3), pp. $375 * 399$. 
Ekelund Robert B., and Robert Tollison. 1981. Mercantilism and Rent-Seeking Society. College Station: Texas A\&M University Press.

Ekelund Robert B., and Robert Tollison. 1989. Politicized Economies: Monarchy, Monopoly, and Mercantilism. College Station: Texas A\&M University Press.

Foucault, Michel. 2004. Sécurité, Territoire, Population. Cours au Collège de France, 1977-1978. Paris: Gallimard et Seuil, 430 pages.

Garrigues, Frédéric. 1998. Les Intendants du Commerce au xviii ${ }^{\circ}$ siècle. Revue d'Histoire Moderne et Contemporaine. 45 (3), pp. 626-661.

Graber, Fréderic. 2011. Du faiseur de projet au projet régulier dans les Travaux Publics $\left(\mathrm{XVIII}^{\mathrm{e}}\right.$-XIX ${ }^{\mathrm{e}}$ siècles) : pour une histoire des projets. Revue d'Histoire Moderne et Contemporaine, pp. 7-33

Grevet, René. 1998. Etre subdélégué d'intendant dans les provinces septentrionales à la fin du XVIIIe siècle. Bulletin de la Société d'Histoire moderne et contemporaine, 1998.

Gruder, Vivian. 1968. The Royal Provincial Intendants: A Governing Elite in Eighteenth Century France. Ithaca, NY : Cornell University Press, 293 p.

Heckscher, Eli. 1935/ 1994. Mercantilism. London: Routledge. 2 vol., 472p. et 417 p.

Hilaire-Perez, Liliane. 1991. Invention and the State in 18th-Century France. Technology and Culture,

Horn, Jeff. 2015. Economic Development in Early Modern France, The Privilege of Liberty, 16501820. Cambridge: Cambridge University Press. 318 pages.

Joël Felix. 1997. Les commis du Contrôle général des finances au xviii ${ }^{\circ}$ siècle, in : L'Administration des finances sous l'Ancien Régime, Colloque tenu à Bercy les 22 et 23 février 1996. Paris : Comité pour l'histoire économique et financière de la France. pp. 81-102.

Johnson, Christopher H. 1995. The Life and Death of Industrial Languedoc, 1700-1920. Oxford: Oxford University Press, 307 pages.

Judges, A.V. 1939. The Idea of a Mercantile State. Transactions of the Royal Historical Society, fourth series, 21.

Kettering, Sharon. 1986. Patrons, Brokers, and Clients in Seventeenth-Century France. New York and Oxford: Oxford University Press. 321 p.

Kettering, Sharon. 1993. Brokerage at the court of Louis XIV. The Historical Journal, 36, pp 69-87

Lafon, Jacqueline-Lucienne, 1979. Les Députés du Commerce et l'Ordonnance de Mars 1673. Paris, Cujas, 153 pages.

Minard, Philippe. 1998. La fortune du colbertisme, Etat et industrie dans la France des Lumières. Paris: Fayard. 505 pages.

Mousnier, Roland, dir. 1985. Un Nouveau Colbert. Paris : SEDES, actes de colloque.

Mukerji, Chandra. 2011. Jurisdiction, inscription, and state formation: administrative modernism and knowledge regime. Theory and Society. 40, pp. 223-245.

Parker, Harold T. 1979. The Bureau of Commerce in 1781 and its Policies with respect to French Industry. Durham, Carolina Academic Press.

Parker, Harold. 1993. An Administrative Bureau during the Old Regime. The Bureau of Commerce and its Relations to French Industry from May 1781 to November 1783. Cranbury, NJ: University of Delaware Press.

Quenet, Maurice. 1978. Un exemple de consultation dans l'administration monarchique au XVIII ${ }^{\circ}$ siècle, Les Nantais et leurs députés au Conseil du Commerce. Annales de Bretagne, 85, pp. 449485.

Rashid, Salim. 1993. Mercantilism : a Rent-Seeking Society? Magnusson, Lars ed. Mercantilist Economics. Dordrecht : Kluwer Publishers. pp. 125-141.

Reynard, Pierre Claude. 1999. Early modern state and enterprises shaping the dialogue between the French monarchy and paper manufacturers. French History. 13 (1), pp. 1-25.

Richet, Denis. 1973. La France moderne : l'esprit des institutions. Paris : Flammarion.

Ricommard, J. 1962-63. Les subdélégués des intendants aux xvii ${ }^{\circ}$ et xviii ${ }^{\circ}$ siècles. L'information historique, 1962 pp. 139-148, 190-95, et 1963 pp. 1-7. 
Rothkrug, Lionel. 1965. Opposition to Louis XIV: the Political and Social Origins of French Enlightement. Princeton: Princeton University Press. 533 pages.

Schaeper, Thomas J. 1983. The French Council of Commerce, 1700-1715. Columbus: Ohio State University. $305 \mathrm{p}$.

Scotchmer, Suzanne, 2004, Innovation and Incentives, Cambridge, MA : MIT Press

Schmoller, Gustav. 1897. The Mercantile System and Its Historical Significance. Fairfield: Augustus Kelley, 95 pages [1989 reprint].

Schmoller, Gustav, Max Lenz, Erich Marcks. 1899. Zu Bismarcks Gedächtnis. Leipzig: Duncker und Humblot. 174 pages.

Schumpeter, Joseph. 1954. History of Economic Analysis. Edited by E. Boody. New York: Oxford University Press.

Smith, David K. 1995. 'Au Bien du Commerce': Economic Discourse and Visions of Society on France. Dissertation, Ann Arbour, 674 p.

Smith, David K. 2002. Structuring Politics in Early Eighteenth-Century France: The Political Innovations of the French Council of Commerce. Journal of Modern History, 74 (3), p. 490-537.

Smith, David K. 2011. Le discourse économique du Bureau du Commerce, 1700-1750. In Le cercle de Vincent de Gournay: Savoirs économiques et pratiques administratives en France au milieu du XVIIIe siècle. Loïc Charles, Frédéric Lefebvre, and Christine Théré (eds). Paris: Institut National d'Études Démographiques, 2011: pp. 31-61.

Sombart, Werner. 1913. Luxury and Capitalism. Ann Arbour: The University of Michigan Press. 200 pages [1967 repint].

Szulman, Eric. 2001. La navigation intérieure de Colbert à la Révolution. Genèse d'une catégorie d'action publique. Thèse d'Etat, Université de Paris-1, 717 pages.

Thomson, J. K. J. 1982. Clermont-de-Lodève 1633-1789. Fluctuations in the prosperity of Languedocian cloth-making town. Cambridge: Cambridge University Press, 501 pages.

Viner, Jacob. 1948. Power versus Plenty as Objectives of Foreign Policy in the Seventeenth and Eighteenth Centuries. World Politics. 1. pp. 61-90.

Weber, Max. 1927. General Economic History. New Brunswick: Transaction Books (1981 reprint), $401 \mathrm{p}$.

Wybo, Bernard. 1936. Le Conseil de commerce et le commerce intérieur de la France au XVIIIe siècle, thèse pour le doctorat. Paris : F. Loviton, $115 \mathrm{p}$. 
Table 1: Distribution of the 267 Requests

\begin{tabular}{|c|c|c|c|}
\hline New venture & $60.5 \%$ & Privilège Granted & $42,3 \%$ \\
\hline Intellectual Property & $10,2 \%$ & PG with Restriction & $29.2 \%$ \\
\hline Renewal/Enlengthement & $12,8 \%$ & Privilège Refused & $28,5 \%$ \\
\hline Extension of Scope / Redefintion & $16,5 \%$ & \multicolumn{2}{|c}{} \\
\cline { 1 - 2 } & &
\end{tabular}

Figure 1: Number of Requested and Granted Categories of privileges

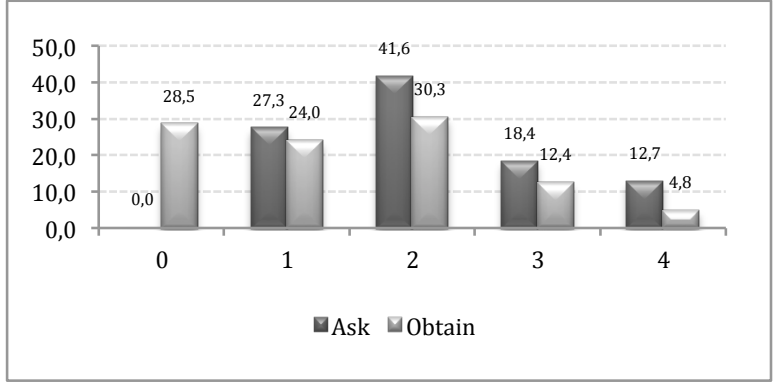

Figure 2: Distribution of Decisions by Categories of Privileges

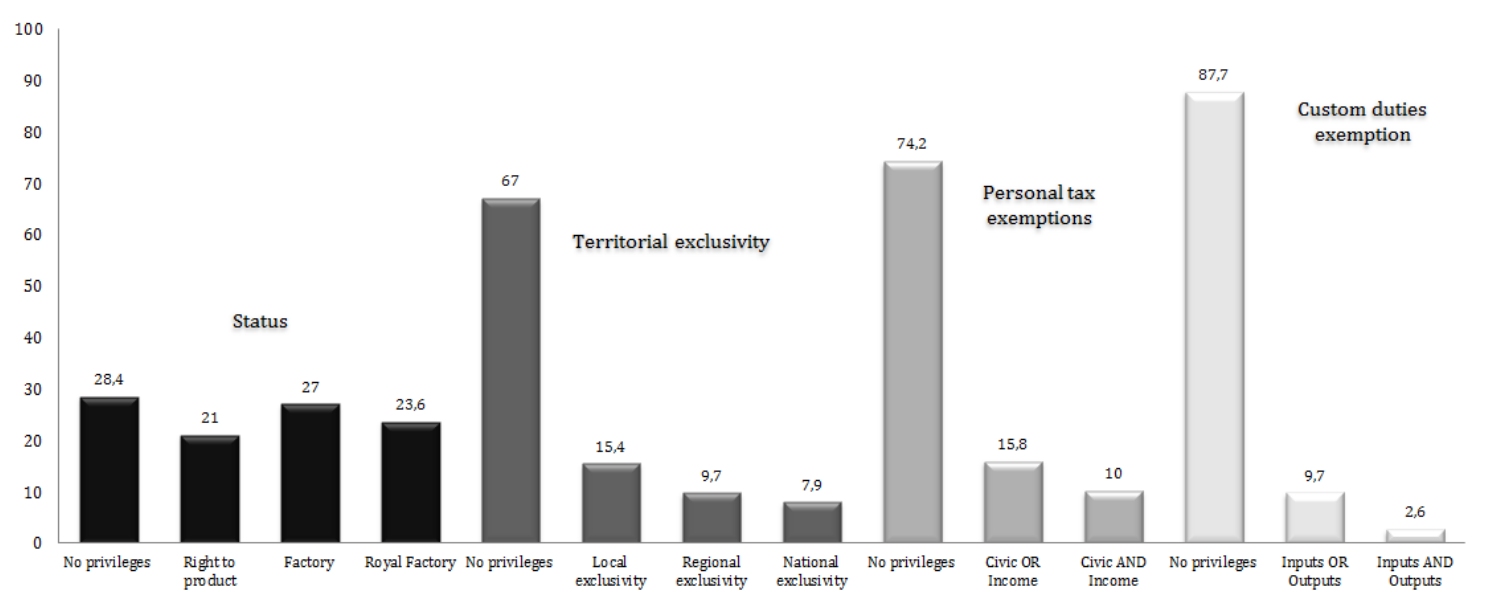


Table 2: Definition and summary statistics of used variables

\begin{tabular}{|c|c|c|c|c|c|}
\hline Variables & Definition & Min. & Max. & Mean & S. D. \\
\hline Obtained & $\begin{array}{l}\text { Number of different categories of privileges obtained by the claimant. } \\
\text { The four categories are defined by their object: production, exclusivity, taxes and custom duties. }\end{array}$ & 0 & 4 & 1,44 & 1,20 \\
\hline \multicolumn{6}{|l|}{ PRIVILEGES } \\
\hline Production & $\begin{array}{l}\text { Ordinal variable which stands for the degree of the privileges of production obtained. } \\
(0=\text { refusal, } 1=\text { right to produce, } 2=\text { manufactory, } 3=\text { royal manufactory })\end{array}$ & 0 & 3 & 1,45 & 1,17 \\
\hline - RightToProduce & Dummy variable equal to 1 when the claimant obtains the right to produce. & 0 & 1 & 0,21 & 0,41 \\
\hline - Factory & Dummy variable equal to 1 when the claimant obtains the status of manufactory. & 0 & 1 & 0,24 & 0,43 \\
\hline - RoyalFactory & Dummy variable equal to 1 when the claimant obtains the status of royal manufactory. & 0 & 1 & 0,26 & 0,44 \\
\hline Exclusivity & $\begin{array}{l}\text { Ordinal variable which stand for the level of territorial exclusivity obtained } \\
(0=\text { no territorial exclusivity, } 1=\text { local, } 2=\text { regional , } 3=\text { =national })\end{array}$ & 0 & 3 & 0,62 & 1,00 \\
\hline - Local & Dummy variable equal to 1 when the claimant obtains local exclusivity. & 0 & 1 & 0,15 & 0,35 \\
\hline - Regional & Dummy variable equal to 1 when the claimant obtains regional exclusivity. & 0 & 1 & 0,10 & 0,30 \\
\hline - National & Dummy variable equal to 1 when the claimant obtains national exclusivity. & 0 & 1 & 0,09 & 0,29 \\
\hline $\operatorname{Tax}$ & $\begin{array}{l}\text { Ordinal variable which stands for the number of taxes exemptions obtained. } \\
(0=\text { no taxes exemptions, } 1=\text { exemptions of civic or income duties, } 2=\text { exemptions of civic \& income } \\
\text { duties })\end{array}$ & 0 & 2 & 0,40 & 0,72 \\
\hline - CivicDuties & Dummy variable equal to 1 when the claimant obtains exemptions of civic duties. & 0 & 1 & 0,23 & 0,42 \\
\hline - IncomeDuties & Dummy variable equal to 1 when the claimant obtains exemptions of income duties & 0 & 1 & 0,32 & 0,70 \\
\hline CustomDuties & $\begin{array}{l}\text { Ordinal variable which stands for the number of custom duties exemptions obtained. } \\
(0=\text { no custom duties exemptions, } 1=\text { exemptions of custom duties on inputs or outputs, } \\
2=\text { exemptions of custom duties on inputs \& outputs })\end{array}$ & 0 & 2 & 0,17 & 0,43 \\
\hline - Inputs & Dummy variable equal to 1 when the claimant obtains exemptions of income duties on inputs. & 0 & 1 & 0,10 & 0,30 \\
\hline - Outputs & Dummy variable equal to 1 when the claimant obtains exemptions of income duties on outputs. & 0 & 1 & 0,07 & 0,25 \\
\hline \multicolumn{6}{|c|}{ ARGUMENTS (ranked by frequency) } \\
\hline Quality & Dummy variable equal to 1 when the commissioners recognize the good quality of the final product & 0 & 1 & 0,32 & 0,47 \\
\hline Subst.Import. & $\begin{array}{l}\text { Dummy variable equal to } 1 \text { when the commissioners state that the production will allow to reduce } \\
\text { the amount of imported products. }\end{array}$ & 0 & 1 & 0,28 & 0,45 \\
\hline LocalEconomy & $\begin{array}{l}\text { Dummy variable equal to } 1 \text { when the commissioners note that the production will make thing better } \\
\text { for the local economic activity }\end{array}$ & 0 & 1 & 0,24 & 0,43 \\
\hline Consumer & $\begin{array}{l}\text { Dummy variable equal to } 1 \text { when the commissioners note that the production will make thing better } \\
\text { for the consumers. }\end{array}$ & 0 & 1 & 0,22 & 0,42 \\
\hline FixedCosts & $\begin{array}{l}\text { Dummy variable equal to } 1 \text { when the commissioners note that the applicant has already engaged a } \\
\text { large amount of costs (financial and/or human) to start his production. }\end{array}$ & 0 & 1 & 0,18 & 0,38 \\
\hline Technic.Innovation & $\begin{array}{l}\text { Dummy variable equal to } 1 \text { when the commissioners accept the production as an invention or as the } \\
\text { import of a foreign technology not yet available in France }\end{array}$ & 0 & 1 & 0,14 & 0,35 \\
\hline Val.LocalResources & $\begin{array}{l}\text { Dummy variable equal to } 1 \text { when the commissioners find the production useful in order to valorize } \\
\text { localized resources (commodities and minerals). }\end{array}$ & 0 & 1 & 0,11 & 0,32 \\
\hline SocialEmployment & $\begin{array}{l}\text { Dummy variable equal to } 1 \text { when the commissioners state that the production will favor social } \\
\text { employment to reduce the amount of imported products }\end{array}$ & 0 & 1 & 0,10 & 0,30 \\
\hline PriorPrivileges & $\begin{array}{l}\text { Dummy variable equal to } 1 \text { when the commissioners refer to prior decisions leading to same kinds of } \\
\text { privileges. }\end{array}$ & 0 & 1 & 0,07 & 0,25 \\
\hline Attract.LaborForce & $\begin{array}{l}\text { Dummy variable equal to } 1 \text { when the commissioners agree that production needs to attract } \\
\text { specialized labor force (most of the time from foreign countries). }\end{array}$ & 0 & 1 & 0,07 & 0,25 \\
\hline \multicolumn{6}{|l|}{ CONTROLS } \\
\hline Year & Year of the demand. & 1724 & 1740 & 1730,9 & 4,91 \\
\hline Luxury & Dummy variable equal to 1 when demands are concerned with luxury product. & 0 & 1 & 0,10 & 0,30 \\
\hline Foreigner & Dummy variable equal to 1 when the claimant is a foreign entrepreneur. & 0 & 1 & 0,07 & 0,26 \\
\hline \multicolumn{6}{|l|}{ SECTOR } \\
\hline Textile & & 0 & 1 & 0,39 & 0,49 \\
\hline Glass & & 0 & 1 & 0,13 & 0,34 \\
\hline Metal & & 0 & 1 & 0,15 & 0,36 \\
\hline Dye & & 0 & 1 & 0,07 & 0,26 \\
\hline Faience & & 0 & 1 & 0,07 & 0,25 \\
\hline Machine-tool & & 0 & 1 & 0,07 & 0,25 \\
\hline Mills & Dummy variables & 0 & 1 & 0,05 & 0,22 \\
\hline Mines & & 0 & 1 & 0,05 & 0,22 \\
\hline Small Manufacturing & & 0 & 1 & 0,03 & 0,18 \\
\hline Forges & & 0 & 1 & 0,02 & 0,15 \\
\hline Services & & 0 & 1 & 0,04 & 0,19 \\
\hline Food & & 0 & 1 & 0,02 & 0,15 \\
\hline
\end{tabular}


Table 4. Ordered Logit Estimations

\begin{tabular}{|c|c|c|c|c|c|}
\hline Dependent variables: & $\begin{array}{c}\text { Obtained } \\
1\end{array}$ & $\begin{array}{c}\text { Production } \\
2 \\
\end{array}$ & $\begin{array}{c}\text { Exclusivity } \\
3\end{array}$ & $\begin{array}{c}\text { Taxes } \\
4\end{array}$ & $\begin{array}{l}\text { CustomDuties } \\
5\end{array}$ \\
\hline \multicolumn{6}{|l|}{ Arguments } \\
\hline Quality & $\begin{array}{c}0.774 * * \\
(0.299)\end{array}$ & $\begin{array}{c}0.943 * * \\
(0.332)\end{array}$ & $\begin{array}{l}0.037 \\
(0.410)\end{array}$ & $\begin{array}{l}0.539 \\
(0.415)\end{array}$ & $\begin{array}{c}-0.576 \\
(0.591)\end{array}$ \\
\hline TradeBalance & $\begin{array}{c}1.263 * * * * \\
(0.324)\end{array}$ & $\begin{array}{c}0.849^{* *} \\
(0.321)\end{array}$ & $\begin{array}{l}0.549 \\
0.395)\end{array}$ & $\begin{array}{c}0.696+1 \\
0.4033 \\
(0.403)\end{array}$ & $\begin{array}{c}1.793 * * * \\
(0.490)\end{array}$ \\
\hline Local.Economy & $\begin{array}{c}1.517 * * * * \\
(0.296)\end{array}$ & $\begin{array}{c}1.434 * * * * \\
(0.314)\end{array}$ & $\begin{array}{c}1.116^{* * *} \\
(0.350)\end{array}$ & $\begin{array}{c}0.672+ \\
(0.374)\end{array}$ & $\begin{array}{l}0.456 \\
(0.511)\end{array}$ \\
\hline Consumer & $\underset{(0.277)}{0.997 * * *}$ & $\underset{(0.294)}{0.960 * *}$ & $\begin{array}{c}0.990 * * \\
(0.366)\end{array}$ & $\begin{array}{l}0.339 \\
(0.390)\end{array}$ & $\begin{array}{l}0.520 \\
(0.486)\end{array}$ \\
\hline Fixed.Costs & $\begin{array}{c}0.914^{*} \\
(0.415)\end{array}$ & $\begin{array}{l}0.421 \\
(0.484)\end{array}$ & $\begin{array}{c}0.976+ \\
(0.499)\end{array}$ & $\begin{array}{l}0.082 \\
(0.588)\end{array}$ & $\begin{array}{l}1.052 \\
(0.7922\end{array}$ \\
\hline Technic.Innovation & $\begin{array}{c}1.886 * * * \\
(0.413)\end{array}$ & $\begin{array}{l}0.447 \\
(0.416)\end{array}$ & $\begin{array}{c}3.319^{* * * *} \\
(0.530)\end{array}$ & $\begin{array}{l}0.419 \\
(0.509)\end{array}$ & $\begin{array}{l}0.448 \\
(0.525)\end{array}$ \\
\hline Val.Local.Resources & $\underset{(0.428)}{0.959 *}$ & $\begin{array}{l}-0.342 \\
(0.463)\end{array}$ & $\begin{array}{l}0.660 \\
(0.417)\end{array}$ & $\begin{array}{c}0.775^{*} \\
(0.250)\end{array}$ & $\frac{-0.174}{(0.620)}$ \\
\hline Social.Employment & $\begin{array}{l}-0.022 \\
(0.410)\end{array}$ & $\begin{array}{l}0.566 \\
(0.460)\end{array}$ & $\begin{array}{c}-1.412^{*} \\
(0.644)\end{array}$ & $\frac{-0.220}{(0.514)}$ & $\frac{-0.136}{(0.675)}$ \\
\hline Prior.Privileges & $\frac{1.096+}{(0.656)}$ & $\begin{array}{c}1.207 * \\
(0.591)\end{array}$ & $\begin{array}{l}0.726 \\
(0.661)\end{array}$ & $\begin{array}{c}1.151 * \\
(0.536)\end{array}$ & $\begin{array}{l}0.010 \\
(0.982)\end{array}$ \\
\hline Attract.Labor.Force & $\begin{array}{l}0.557 \\
(0.657)\end{array}$ & $\begin{array}{l}0.623 \\
(0.680)\end{array}$ & $\begin{array}{l}0.354 \\
(0.826)\end{array}$ & $\begin{array}{c}1.490^{*} \\
(0.655)\end{array}$ & $\begin{array}{c}-1.046 \\
(0.741)\end{array}$ \\
\hline \multicolumn{6}{|l|}{ Controls } \\
\hline Year & $\begin{array}{l}0.021 \\
(0.020)\end{array}$ & $\begin{array}{l}0.026 \\
(0.020)\end{array}$ & $\begin{array}{l}0.007 \\
(0.025)\end{array}$ & $\begin{array}{c}-0.041 \\
(0.028)\end{array}$ & $\begin{array}{c}-0.046 \\
(0.039)\end{array}$ \\
\hline Luxury & $\frac{-0.236}{(0.462)}$ & $\begin{array}{c}-0.698 \\
(0.780)\end{array}$ & $\frac{-0.844}{(0.756)}$ & $\begin{array}{l}0.203 \\
(0.571)\end{array}$ & $\begin{array}{r}-0.385 \\
(0.758)\end{array}$ \\
\hline Foreign & $\begin{array}{c}-0.4276 \\
0.21 \\
\end{array}$ & $\begin{array}{l}0.879 \\
(0.658)\end{array}$ & $\begin{array}{r}-1.140) \\
0.007 \\
\end{array}$ & $\begin{array}{r}0.688 \\
-0.041 \\
\end{array}$ & $\begin{array}{r}-0.241 \\
-0.046 \\
\end{array}$ \\
\hline Sector Dummy & Yes & Yes & Yes & Yes & Yes \\
\hline Intercept & $\begin{array}{l}36.381 \\
(35.378) \\
38.057 \\
(35.407) \\
40.069 \\
(35.434) \\
41.567 \\
(35.466) \\
\end{array}$ & $\begin{array}{c}46.498 \\
(34.007) \\
47.054 \\
(34.0177) \\
48.640 \\
(34.024) \\
.\end{array}$ & $\begin{array}{l}14.324 \\
(44.0211 \\
15.463 \\
(44.022) \\
16.722 \\
(44.047)\end{array}$ & $\begin{array}{c}-69.452 \\
(48.894) \\
-68.902 \\
(48.927) \\
-68.108 \\
(48.927) \\
.\end{array}$ & $\begin{array}{c}-76.366 \\
-67.420) \\
-74.564 \\
(67.331) \\
\vdots \\
\vdots\end{array}$ \\
\hline $\begin{array}{l}\text { Adj. } \mathrm{R}^{2} \\
\text { Observations }\end{array}$ & $\begin{array}{l}0.19 \\
267\end{array}$ & $\begin{array}{l}0.15 \\
267 \\
\end{array}$ & $\begin{array}{l}0.19 \\
267 \\
\end{array}$ & $\begin{array}{l}0.13 \\
267 \\
\end{array}$ & $\begin{array}{l}0.13 \\
267\end{array}$ \\
\hline
\end{tabular}

Table 5. Ordered Logit Estimations - Marginal Effects

\begin{tabular}{|c|c|c|c|c|c|}
\hline Dependent variables: & $\begin{array}{c}\operatorname{Pr}(\text { Obtained })=0 \\
6\end{array}$ & $\begin{array}{c}\operatorname{Pr}(\text { Production })=0 \\
7\end{array}$ & $\begin{array}{c}\operatorname{Pr}(\text { Exclusivity })=0 \\
8\end{array}$ & $\begin{array}{c}\operatorname{Pr}(\text { Taxes })=0 \\
9\end{array}$ & $\begin{array}{c}\operatorname{Pr}(\text { CustomDuties })=0 \\
10\end{array}$ \\
\hline \multicolumn{6}{|l|}{ Arguments } \\
\hline Quality & $\begin{array}{c}-0.125^{*} \\
(0.050)\end{array}$ & $\begin{array}{c}-0.214 * * \\
(0.073)\end{array}$ & $\begin{array}{c}-0.008 \\
(0.085)\end{array}$ & $\begin{array}{c}-0.094 \\
(0.071)\end{array}$ & $\begin{array}{l}0.047 \\
(0.047)\end{array}$ \\
\hline TradeBalance & $\begin{array}{c}-0.203 * * * \\
(0.051)\end{array}$ & $\begin{array}{c}-0.192 * * \\
(0.074)\end{array}$ & $\begin{array}{l}-0.114 \\
(0.082)\end{array}$ & $\begin{array}{c}-0.121+ \\
(0.072)\end{array}$ & $\underset{(0.038)}{-0.146 * * *}$ \\
\hline Local.Economy & $\underset{(0.048)}{-0.244 * * *}$ & $\begin{array}{c}-0.325 * * * \\
(0.071)\end{array}$ & $\begin{array}{c}-0.231 * * \\
(0.072)\end{array}$ & $\begin{array}{c}-0.117+ \\
(0.064)\end{array}$ & $\underset{(0.041)}{-0.037}$ \\
\hline Consumer & $\begin{array}{c}-0.161^{* * * *} \\
(0.045)\end{array}$ & $\begin{array}{c}-0.218^{* * *} \\
(0.067)\end{array}$ & $\begin{array}{c}-0.205 * * \\
(0.077)\end{array}$ & $\begin{array}{l}-0.059 \\
(0.068)\end{array}$ & $\begin{array}{c}-0.042 \\
(0.040)\end{array}$ \\
\hline Fixed.Costs & $\begin{array}{c}-0.147 * \\
(0.066)\end{array}$ & $\begin{array}{c}-0.095 \\
(0.109)\end{array}$ & $\begin{array}{c}-0.202+ \\
(0.104)\end{array}$ & $\begin{array}{l}-0.014 \\
(0.103)\end{array}$ & $\begin{array}{c}-0.096^{*} \\
(0.043)\end{array}$ \\
\hline Technic.Innovation & $\begin{array}{c}-0.304 * * * * \\
(0.065)\end{array}$ & $\begin{array}{l}-0.101 \\
(0.094)\end{array}$ & $\begin{array}{c}-0.687 * * * * \\
(0.123)\end{array}$ & $\begin{array}{c}-0.073 \\
(0.089)\end{array}$ & $\begin{array}{l}-0.037 \\
(0.042)\end{array}$ \\
\hline Val.Local.Resources & $\begin{array}{l}-0.155^{*} \\
(0.068)\end{array}$ & $\begin{array}{l}0.078 \\
(0.105)\end{array}$ & $\begin{array}{l}-0.137 \\
(0.087)\end{array}$ & $\begin{array}{l}-0.135 \\
(0.091)\end{array}$ & $\begin{array}{l}0.014 \\
(0.050)\end{array}$ \\
\hline Social.Employment & $\begin{array}{l}0.004 \\
(0.066)\end{array}$ & $\begin{array}{l}-0.128 \\
(0.104)\end{array}$ & $\begin{array}{c}0.292 * \\
(0.133)\end{array}$ & $\begin{array}{l}0.038 \\
(0.090)\end{array}$ & $\begin{array}{l}0.011 \\
(0.055)\end{array}$ \\
\hline Prior.Privileges & $\begin{array}{c}-0.177+ \\
(0.104)\end{array}$ & $\begin{array}{c}-0.274^{*} \\
(0.134)\end{array}$ & $\begin{array}{c}-0.150 \\
(0.138)\end{array}$ & $\begin{array}{c}-0.200 * \\
(0.093)\end{array}$ & $\begin{array}{l}-0.001 \\
(0.080)\end{array}$ \\
\hline Attract.Labor.Force & $\begin{array}{l}-0.090 \\
(0.106)\end{array}$ & $\begin{array}{l}-0.141 \\
(0.154)\end{array}$ & $\begin{array}{l}-0.073 \\
(0.172)\end{array}$ & $\begin{array}{c}-0.259^{*} \\
(0.113)\end{array}$ & $\begin{array}{l}0.085 \\
(0.060)\end{array}$ \\
\hline \multicolumn{6}{|l|}{ Controls } \\
\hline Year & $\begin{array}{c}-0.003 \\
(0.003)\end{array}$ & $\begin{array}{l}-0.006 \\
(0.004)\end{array}$ & 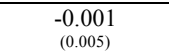 & $\begin{array}{l}0.007 \\
(0.005)\end{array}$ & $\begin{array}{l}0.004 \\
(0.003)\end{array}$ \\
\hline Luxury & 0.038 & 0.158 & 0.175 & -0.035 & 0.031 \\
\hline Foreign & $\begin{array}{l}(0.074) \\
0.044\end{array}$ & $\begin{array}{c}(0.1777) \\
-0.356 * *\end{array}$ & $\begin{array}{l}(0.156) \\
0.237 \\
0\end{array}$ & $\begin{array}{l}(0.099) \\
-0.120 \\
-(0.084)\end{array}$ & $\begin{array}{l}(0.062) \\
0.020\end{array}$ \\
\hline
\end{tabular}


Table 6. Logit Estimations - Privileges of Production

\begin{tabular}{|c|c|c|c|}
\hline \multirow{3}{*}{$\begin{array}{l}\text { Dependent variables: } \\
\text { Model: }\end{array}$} & RighToProd. & Manuf. & RoyalManuf. \\
\hline & logit & logit & logit \\
\hline & 11 & 12 & 13 \\
\hline \multicolumn{4}{|l|}{ Arguments } \\
\hline Quality & $\begin{array}{c}0.813^{*} \\
(0.385)\end{array}$ & $\begin{array}{l}-0.648 \\
(0.417)\end{array}$ & $\begin{array}{c}1.290 * * \\
(0.403)\end{array}$ \\
\hline TradeBalance & $\begin{array}{l}-0.163 \\
(0.417)\end{array}$ & $\begin{array}{c}1.094 * * \\
(0.403)\end{array}$ & $\begin{array}{l}0.368 \\
(0.434)\end{array}$ \\
\hline Local.Economy & $\begin{array}{l}-0.135 \\
(0.430)\end{array}$ & $\begin{array}{c}1.103 * * \\
(0.381)\end{array}$ & $\begin{array}{c}0.972 * \\
(0.383)\end{array}$ \\
\hline Consumer & $\begin{array}{l}0.434 \\
(0.372)\end{array}$ & $\begin{array}{l}0.595 \\
(0.380)\end{array}$ & $\begin{array}{l}0.458 \\
(0.396)\end{array}$ \\
\hline Fixed.Costs & $\begin{array}{l}0.173 \\
(0.517)\end{array}$ & $\begin{array}{l}-0.211 \\
(0.539)\end{array}$ & $\begin{array}{l}0.647 \\
(0.473)\end{array}$ \\
\hline Technic.Innovation & $\begin{array}{c}1.053^{* *} \\
(0.398)\end{array}$ & $\begin{array}{l}1.023^{*} \\
(0.464)\end{array}$ & $\begin{array}{l}-0.501 \\
(0.675)\end{array}$ \\
\hline Val.Local.Resources & $\begin{array}{l}0.318 \\
(0.588)\end{array}$ & $\begin{array}{l}0.9047 * \\
0.452)\end{array}$ & $\begin{array}{l}-0.080 \\
(0.621)\end{array}$ \\
\hline Social.Employment & $\begin{array}{l}0.433 \\
(0.610)\end{array}$ & $\begin{array}{l}0.250 \\
(0.557)\end{array}$ & $\begin{array}{l}0.305 \\
(0.529)\end{array}$ \\
\hline Prior.Privileges & $\begin{array}{l}-0.801 \\
(0.859)\end{array}$ & $\begin{array}{l}0.761 \\
(0.616)\end{array}$ & $\begin{array}{l}0.975 \\
(0.638)\end{array}$ \\
\hline Attract.Labor.Force & $\begin{array}{l}-0.312 \\
(0.757)\end{array}$ & $\begin{array}{l}0.193 \\
(0.651)\end{array}$ & $\begin{array}{l}0.312 \\
(0.662)\end{array}$ \\
\hline \multicolumn{4}{|l|}{ Controls } \\
\hline Year & $\begin{array}{l}0.032 \\
(0.029)\end{array}$ & $\begin{array}{c}0.048+ \\
(0.028)\end{array}$ & $\begin{array}{c}-0.015 \\
(0.028)\end{array}$ \\
\hline Luxury & $\begin{array}{l}0.497 \\
(0.599)\end{array}$ & $\begin{array}{l}-1.593 \\
(0.996)\end{array}$ & $\begin{array}{l}0.216 \\
(0.638)\end{array}$ \\
\hline Foreign & $\begin{array}{r}-1.152 \\
(0.769) \\
\end{array}$ & $\begin{array}{c}-2.206+ \\
(1.195) \\
\end{array}$ & $\begin{array}{c}1.519^{* *} \\
(0.523)\end{array}$ \\
\hline Sector Dummy & Yes & Yes & Yes \\
\hline Intercept & $\begin{array}{l}-61.662 \\
(52.426) \\
\end{array}$ & $\begin{array}{r}-73.583 \\
(48.729) \\
\end{array}$ & $\begin{array}{l}16.156 \\
(47.940)\end{array}$ \\
\hline Adj. R2 & 0.10 & 0.16 & $\begin{array}{c}0.19 \\
2 \gamma\end{array}$ \\
\hline Observations & 267 & 267 & 267 \\
\hline
\end{tabular}

Table 7. Logit Estimations -Privileges of Territorial Exclusivity

\begin{tabular}{|c|c|c|c|}
\hline \multirow{3}{*}{$\begin{array}{l}\text { Dependent variables: } \\
\text { Model: }\end{array}$} & Local & Regional & National \\
\hline & & logit & \\
\hline & 14 & 15 & 16 \\
\hline \multicolumn{4}{|l|}{ Arguments } \\
\hline Quality & $\begin{array}{l}0.446 \\
(0.468)\end{array}$ & $\begin{array}{l}-0.398 \\
(0.592)\end{array}$ & $\begin{array}{c}-0.201 \\
(0.630)\end{array}$ \\
\hline TradeBalance & $\frac{-0.412}{(0.522)}$ & $\begin{array}{c}1.224 * \\
(0.611)\end{array}$ & $\begin{array}{l}0.645 \\
(0.718)\end{array}$ \\
\hline Local.Economy & $\begin{array}{c}1.114 * \\
(0.449)\end{array}$ & $\begin{array}{c}0.894+ \\
(0.476)\end{array}$ & $\begin{array}{c}-0.661 \\
(0.835)\end{array}$ \\
\hline Consumer & $\begin{array}{l}0.247 \\
(0.468)\end{array}$ & $\begin{array}{l}0.118 \\
(0.529)\end{array}$ & $\begin{array}{c}2.426^{* *} \\
(0.813)\end{array}$ \\
\hline Fixed.Costs & $\frac{1.032+}{(0.534)}$ & $\begin{array}{l}0.297 \\
(0.694)\end{array}$ & $\begin{array}{l}0.953 \\
(1.005)\end{array}$ \\
\hline Technic.Innovation & $\begin{array}{l}0.137 \\
(0.579)\end{array}$ & $\begin{array}{l}0.781 \\
(0.551)\end{array}$ & $\begin{array}{c}4.7155^{* * * *} \\
(0.863)\end{array}$ \\
\hline Val.Local.Resources & $\begin{array}{c}0.981+ \\
(0.558)\end{array}$ & $\begin{array}{l}0.815 \\
(0.660)\end{array}$ & $\begin{array}{c}-1.540 \\
(1.556)\end{array}$ \\
\hline Social.Employment & $\begin{array}{l}-1.007 \\
(0.797)\end{array}$ & $\begin{array}{c}-1.908 \\
(1.243)\end{array}$ & $\begin{array}{l}0.046 \\
(0.993)\end{array}$ \\
\hline Prior.Privileges & $\begin{array}{l}0.203 \\
(0.781)\end{array}$ & $\frac{-0.945}{(1.250)}$ & $\begin{array}{l}1.787 \\
(1.222)\end{array}$ \\
\hline Attract.Labor.Force & $\frac{-1.064}{(0.961)}$ & $\begin{array}{l}0.132 \\
(0.903)\end{array}$ & $\underset{(1.056)}{2.396 *}$ \\
\hline \multicolumn{4}{|l|}{ Controls } \\
\hline Year & $\begin{array}{l}0.047 \\
(0.047)\end{array}$ & $\begin{array}{l}0.044 \\
(0.051)\end{array}$ & $\begin{array}{l}0.222 \\
(0.637)\end{array}$ \\
\hline Luxury & $\begin{array}{l}1.045 \\
(0.773)\end{array}$ & $\begin{array}{r}-79.101 \\
(88.756)\end{array}$ & $\begin{array}{l}7.620 \\
(5.389)\end{array}$ \\
\hline Foreign & $\begin{array}{r}-83.067 \\
(80.877)\end{array}$ & $\begin{array}{l}0.980 \\
(0.627)\end{array}$ & $\begin{array}{l}2.109 \\
(1.814)\end{array}$ \\
\hline Sector Dummy & Yes & Yes & Yes \\
\hline Intercept & $\begin{array}{l}-47.501 \\
(56.140) \\
\end{array}$ & $\begin{array}{r}1.863 \\
(68.696) \\
\end{array}$ & $\begin{array}{c}-27.856 \\
(82.269) \\
\end{array}$ \\
\hline Adj. $\mathrm{R}^{2}$ & 0.19 & 0.21 & 0.44 \\
\hline Observations & 267 & 267 & 267 \\
\hline
\end{tabular}


Table 8. Logit Estimations -Privileges of Tax and Custom Duties

Exemptions

\begin{tabular}{|c|c|c|c|c|}
\hline \multirow{2}{*}{$\begin{array}{l}\text { Dependent variables: } \\
\text { Model: }\end{array}$} & CivicDuties & IncomeTax & Inputs & Outputs \\
\hline & 17 & 18 & 19 & 20 \\
\hline \multicolumn{5}{|l|}{ Arguments } \\
\hline Quality & $\begin{array}{l}0.397 \\
(0.448)\end{array}$ & $\begin{array}{l}0.404 \\
(0.502)\end{array}$ & $\begin{array}{c}-1.900 \\
(1.266)\end{array}$ & $\begin{array}{l}0.368 \\
(0.631)\end{array}$ \\
\hline TradeBalance & $\begin{array}{l}0.706 \\
(0.449)\end{array}$ & $\begin{array}{l}0.417 \\
(0.475)\end{array}$ & $\begin{array}{c}2.814 * * \\
(0.932)\end{array}$ & $\underset{(0.549)}{1.711^{* *}}$ \\
\hline Local.Economy & $\begin{array}{c}0.678+ \\
(0.397)\end{array}$ & $\begin{array}{l}0.554 \\
(0.456)\end{array}$ & $\begin{array}{c}-1.174 \\
(0.715)\end{array}$ & $\begin{array}{l}-0.542 \\
(0.742)\end{array}$ \\
\hline Consumer & $\begin{array}{l}0.397 \\
(0.403)\end{array}$ & $\begin{array}{l}0.489 \\
(0.458)\end{array}$ & $\begin{array}{l}0.978 \\
(0.695)\end{array}$ & $\begin{array}{l}0.741 \\
(0.513)\end{array}$ \\
\hline Fixed.Costs & $\begin{array}{l}0.284 \\
(0.540)\end{array}$ & $\begin{array}{l}0.317 \\
0.599\end{array}$ & 1.574 & 1.167 \\
\hline Technic.Innovation & $\begin{array}{l}(0.540) \\
0.507 \\
(0.494)\end{array}$ & $\begin{array}{l}0.212 \\
0.579)\end{array}$ & $\begin{array}{l}1.035 \\
(1.181)\end{array}$ & $\begin{array}{l}0.009 \\
(0.718)\end{array}$ \\
\hline Val.Local.Resources & $\begin{array}{l}0.698 \\
(0.551)\end{array}$ & $\begin{array}{l}0.864 \\
(0.606)\end{array}$ & $\begin{array}{l}-0.101 \\
(0.838)\end{array}$ & $\frac{-0.520}{(0.799)}$ \\
\hline Social.Employment & $\begin{array}{l}-0.210 \\
(0.621)\end{array}$ & $\begin{array}{c}-0.026 \\
(0.629)\end{array}$ & $\begin{array}{l}0.514 \\
(1.134)\end{array}$ & $\begin{array}{l}0.242 \\
(0.787)\end{array}$ \\
\hline Prior:Privileges & $\begin{array}{c}1.211+ \\
(0.650)\end{array}$ & $\begin{array}{l}0.900 \\
(0.628)\end{array}$ & $\begin{array}{c}-0.369 \\
(1.100)\end{array}$ & $\begin{array}{l}0.811 \\
(0.973)\end{array}$ \\
\hline Attract.Labor.Force & $\begin{array}{c}1.224+ \\
(0.635)\end{array}$ & $\begin{array}{c}1.584^{*} \\
(0.661)\end{array}$ & $\begin{array}{c}1.757+ \\
(1.061)\end{array}$ & $\begin{array}{c}-0.561 \\
(0.882)\end{array}$ \\
\hline \multicolumn{5}{|l|}{ Controls } \\
\hline Year & $\begin{array}{c}-0.038 \\
(0.031)\end{array}$ & $\begin{array}{c}-0.064+ \\
(0.033)\end{array}$ & $\begin{array}{l}0.105 \\
(0.077)\end{array}$ & $\begin{array}{l}0.068 \\
(0.059)\end{array}$ \\
\hline Luxury & $\begin{array}{l}0.030 \\
(0.590)\end{array}$ & $\begin{array}{l}0.388 \\
(0.638)\end{array}$ & $\begin{array}{l}0.596 \\
(1.296)\end{array}$ & $\begin{array}{l}0.710 \\
(0.862)\end{array}$ \\
\hline Foreign & $\begin{array}{l}0.3 .391) \\
0.727 \\
(0.606)\end{array}$ & $\begin{array}{l}0.0 .901 \\
(0.594) \\
\end{array}$ & $\begin{array}{r}-0.250) \\
(1.675) \\
\end{array}$ & $\begin{array}{r}-1.320) \\
(1.129) \\
\end{array}$ \\
\hline Sector Dummy & Yes & Yes & Yes & Yes \\
\hline Intercept & $\begin{array}{r}63.879 \\
(53.739) \\
\end{array}$ & $\begin{array}{c}108.004+ \\
(56.636)\end{array}$ & $\begin{array}{r}-187.301 \\
(134.613) \\
\end{array}$ & $\begin{array}{r}-121.308 \\
(103.068) \\
\end{array}$ \\
\hline Adj. $\mathrm{R}^{2}$ & 0.16 & 0.19 & 0.28 & 0.22 \\
\hline Observations & 267 & 267 & 267 & 267 \\
\hline
\end{tabular}




\section{Appendix}

Table A1. Correlations

\begin{tabular}{|c|c|c|c|c|c|c|c|c|c|c|c|c|c|c|c|c|c|c|c|c|c|c|c|c|c|c|c|}
\hline & 1 & 2 & 3 & 4 & 5 & 6 & 7 & 8 & 9 & 10 & 11 & 12 & 13 & 14 & 15 & 16 & 17 & 18 & 19 & 20 & 21 & 22 & 23 & 24 & 25 & 26 & 27 \\
\hline \multicolumn{28}{|l|}{ 1. Obtained } \\
\hline 2. Production & 0.671 & & & & & & & & & & & & & & & & & & & & & & & & & & \\
\hline 3. Exclusivity & 0.609 & 0.291 & & & & & & & & & & & & & & & & & & & & & & & & & \\
\hline 4. TaxExemptions & 0.679 & 0.498 & 0.200 & & & & & & & & & & & & & & & & & & & & & & & & \\
\hline 5. CustomDuties & 0.558 & 0.264 & 0.163 & 0.418 & & & & & & & & & & & & & & & & & & & & & & & \\
\hline 6. RightToProduce & 0.512 & 0.646 & 0.340 & 0.229 & 0.234 & & & & & & & & & & & & & & & & & & & & & & \\
\hline 7. Manufacture & 0.453 & 0.745 & 0.131 & 0.430 & 0.199 & 0.176 & & & & & & & & & & & & & & & & & & & & & \\
\hline 8. RoyalManufacture & 0.453 & 0.745 & 0.131 & 0.430 & 0.199 & 0.176 & 1.000 & & & & & & & & & & & & & & & & & & & & \\
\hline 9. Local & 0.404 & 0.231 & 0.186 & 0.129 & 0.046 & 0.182 & 0.155 & 0.155 & & & & & & & & & & & & & & & & & & & \\
\hline 10. Regional & 0.377 & 0.244 & 0.488 & 0.159 & 0.152 & 0.299 & 0.204 & 0.204 & -0.140 & & & & & & & & & & & & & & & & & & \\
\hline 11. National & 0.262 & 0.061 & 0.740 & 0.062 & 0.061 & 0.102 & -0.064 & -0.064 & -0.124 & -0.096 & & & & & & & & & & & & & & & & & \\
\hline 12. CivicDuties & 0.662 & 0.485 & 0.204 & 0.859 & 0.408 & 0.283 & 0.384 & 0.384 & 0.049 & 0.190 & 0.079 & & & & & & & & & & & & & & & & \\
\hline 13. IncomeTax & 0.546 & 0.435 & 0.119 & 0.902 & 0.277 & 0.124 & 0.415 & 0.415 & 0.158 & 0.080 & 0.011 & 0.631 & & & & & & & & & & & & & & & \\
\hline 14. Inputs & 0.451 & 0.285 & 0.177 & 0.473 & 0.551 & 0.236 & 0.181 & 0.181 & 0.034 & 0.236 & 0.021 & 0.414 & 0.382 & & & & & & & & & & & & & & \\
\hline 15. Outputs & 0.357 & 0.164 & 0.054 & 0.226 & 0.750 & 0.187 & 0.133 & 0.133 & -0.047 & 0.092 & 0.018 & 0.213 & 0.157 & 0.318 & & & & & & & & & & & & & \\
\hline 16. Quality & 0.323 & 0.311 & 0.117 & 0.198 & 0.074 & 0.076 & 0.324 & 0.324 & 0.081 & 0.031 & 0.080 & 0.198 & 0.187 & -0.009 & 0.170 & & & & & & & & & & & & \\
\hline 17. TradeBalance & 0.387 & 0.354 & 0.162 & 0.282 & 0.299 & 0.270 & 0.233 & 0.233 & -0.005 & 0.167 & 0.071 & 0.261 & 0.224 & 0.281 & 0.258 & 0.381 & & & & & & & & & & & \\
\hline 18. LocalEconomy & 0.310 & 0.313 & 0.104 & 0.170 & 0.064 & 0.240 & 0.131 & 0.131 & 0.214 & 0.134 & -0.071 & 0.155 & 0.146 & 0.077 & -0.038 & -0.038 & 0.077 & & & & & & & & & & \\
\hline 19. Consumer & 0.235 & 0.230 & 0.182 & 0.092 & 0.050 & 0.125 & 0.092 & 0.092 & 0.078 & 0.041 & 0.150 & 0.070 & 0.067 & -0.018 & 0.082 & 0.146 & 0.023 & 0.140 & & & & & & & & & \\
\hline 20. FixedCosts & 0.313 & 0.232 & 0.130 & 0.267 & 0.200 & 0.049 & 0.253 & 0.253 & 0.119 & 0.058 & 0.058 & 0.226 & 0.245 & 0.267 & 0.170 & 0.344 & 0.294 & 0.097 & -0.038 & & & & & & & & \\
\hline 21. Technic.Innovation & 0.228 & 0.021 & 0.495 & 0.020 & 0.046 & 0.045 & -0.059 & -0.059 & -0.012 & 0.060 & 0.546 & 0.034 & -0.005 & 0.087 & 0.010 & 0.082 & 0.011 & -0.145 & 0.011 & -0.023 & & & & & & & \\
\hline 22. Val.LocalResources & 0.264 & 0.113 & 0.102 & 0.238 & 0.047 & 0.157 & 0.005 & 0.005 & 0.185 & 0.129 & -0.057 & 0.191 & 0.218 & 0.085 & -0.013 & 0.058 & 0.110 & 0.330 & 0.050 & 0.169 & -0.100 & & & & & & \\
\hline 23. SocialEmployment & 0.096 & 0.171 & -0.095 & 0.059 & 0.063 & 0.092 & 0.115 & 0.115 & -0.035 & -0.065 & -0.049 & 0.069 & 0.080 & 0.067 & 0.045 & 0.058 & 0.139 & 0.163 & -0.081 & 0.263 & -0.090 & 0.129 & & & & & \\
\hline 24. PriorPrivileges & 0.167 & 0.199 & 0.065 & 0.161 & 0.053 & 0.100 & 0.180 & 0.180 & 0.017 & -0.034 & 0.095 & 0.194 & 0.161 & 0.042 & 0.095 & 0.095 & 0.115 & 0.028 & -0.026 & 0.132 & -0.010 & 0.057 & 0.173 & & & & \\
\hline 25. AtractLaborForce & 0.220 & 0.174 & 0.114 & 0.342 & 0.053 & 0.131 & 0.144 & 0.144 & -0.026 & 0.070 & 0.095 & 0.268 & 0.323 & 0.206 & 0.038 & 0.162 & 0.287 & 0.064 & 0.011 & 0.380 & $\begin{array}{l}-0.056 \\
-0.056\end{array}$ & 0.205 & 0.070 & 0.058 & & & \\
\hline 26. Year & -0.094 & -0.002 & -0.067 & -0.222 & -0.080 & 0.153 & -0.100 & -0.100 & 0.021 & -0.018 & -0.075 & -0.161 & -0.196 & -0.134 & 0.015 & -0.097 & -0.090 & -0.032 & 0.067 & -0.216 & -0.078 & -0.089 & -0.087 & -0.122 & -0.180 & & \\
\hline 27. Foreigner & 0.062 & 0.010 & 0.049 & 0.116 & 0.016 & -0.119 & 0.072 & 0.072 & 0.059 & -0.086 & 0.095 & 0.083 & 0.121 & 0.042 & 0.038 & 0.062 & 0.047 & 0.028 & 0.049 & 0.050 & 0.126 & 0.106 & -0.086 & 0.058 & 0.058 & -0.158 & \\
\hline 28. Luxury & -0.032 & 0.138 & -0.062 & 0.071 & 0.017 & -0.033 & 0.207 & 0.207 & -0.131 & -0.101 & 0.059 & 0.094 & 0.103 & 0.012 & -0.040 & 0.088 & 0.111 & -0.083 & -0.097 & 0.044 & -0.040 & -0.064 & -0.011 & 0.084 & 0.029 & -0.001 & 0.193 \\
\hline
\end{tabular}


Table A2. Arguments

\begin{tabular}{|c|c|c|c|}
\hline Quality ${ }^{+}$ & 30.3 & Positive & $\begin{array}{l}\text { All the arguments that refer to the quality of production and unique know-how that have been developed by the contractor and } \\
\text { should be protected (not the technology, coded as "Technical Innovation" above). }\end{array}$ \\
\hline Trade Balance & 27.3 & Positive & Development of production for the domestic market (substitution for imports) and for the development of exports. \\
\hline Local Economy + & 24.7 & Positive & $\begin{array}{l}\text { Arguments that insist on the dimension of economic activity and/or market size and demand support. The important point here is } \\
\text { the local / regional character of development. }\end{array}$ \\
\hline Consumer+ & 21.7 & Positive & Explicit reference to the price and/or quality in a logical demand side and utility for consumers (usually local). \\
\hline Fixed Costs & 16.5 & Positive & Argument that refers to the fact that significant financial and/or human investment has been made \\
\hline Restriction of Competition & 13.5 & Negative & $\begin{array}{l}\text { Argument that refers to the fact that granting a privilege would lead to give an unfair advantage to a competitor or to a distortion which } \\
\text { would prove to be inefficient in terms of competitive selection (including fiscal distortion). }\end{array}$ \\
\hline Absence of Innovation & 10.5 & Negative & Arguments put forward when the know-how associated with the application is already widely available. \\
\hline Social Employment & 9.7 & Positive & $\begin{array}{l}\text { Arguments that refer to the fact that the population of the region in general will be better able to work, especially for poor and } \\
\text { hospitals residents. The argument is different from the "Local Economy +" in the sense that the problem of absorption of } \\
\text { underemployment must be explicitly mentioned. }\end{array}$ \\
\hline Precedents - & 7.9 & Negative & Reference to similar previous privileges refused to a third party. \\
\hline $\begin{array}{l}\text { Prior Property Rights } \\
\text { Infringement }\end{array}$ & 7.5 & Negative & Interference with prior property rights (i.e. with other privileges). \\
\hline
\end{tabular}




\begin{tabular}{|c|c|c|c|}
\hline Attract Labor Force & 6.4 & Positive & Need to draw on the workforce, both local and foreign (always skilled workers). \\
\hline Quality- & 4.9 & Negative & $\begin{array}{l}\text { All the arguments that refer to the fact that the production quality and/or skills are low and no (or no longer) warrant protection. It is not } \\
\text { know-how and technologies that have become commonplace, but explicitly poor performance. }\end{array}$ \\
\hline Uncertainty/Incompleteness & 4.1 & Negative & $\begin{array}{l}\text { Does not refer to additional investigations in the case of incomplete information, but rather when the projects are so hazy and vague that it } \\
\text { is impossible to determine either the benefits costs and risks (unlike the case of projects identified as "too risky") }\end{array}$ \\
\hline Statutes \& Royal Decrees - & 3.4 & Negative & Law and jurisprudence on which the council relies to refuse the privileges (outside, of course, the jurisprudence about privileges). \\
\hline Fiscal Costs & 3.4 & Positive & Calculation cost / benefit of the State. \\
\hline Industrial risk & 3 & Negative & Arguments put forward when there is uncertainty about the feasibility of the project or the idea that seems too risky. \\
\hline Lack of Realization & 2.2 & Negative & Situation where the privilege is explicitly removed or cancelled for lack of the exercise of a privilege granted in the past. \\
\hline Statutes \& Royal Decrees + & 1.9 & Positive & Law and jurisprudence on which the council relies to grant the privileges (outside, of course, the jurisprudence about privileges). \\
\hline Consumer- & 1.5 & Negative & \\
\hline $\begin{array}{l}\text { Custom \& Common } \\
\text { Practices }+\end{array}$ & 1.1 & Positive & References to practices and factual situations which are not necessarily codified to grant the privilege. \\
\hline $\begin{array}{l}\text { Custom \& Common } \\
\text { Practices - }\end{array}$ & 1.1 & Negative & References to practices and factual situations that are not necessarily codified to refuse the privilege. \\
\hline Local Economy- & 1.1 & Negative & Argument that insists on the potential negative effect for the local economic activity and/or market size and demand support. \\
\hline
\end{tabular}


